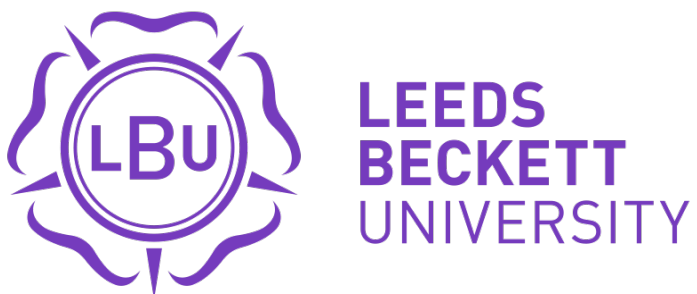

Citation:

Nasir, MA and Bahmani-Oskooee, M (2019) Asymmetric J-curve: Evidence from Industry Trade between U.S. and U.K. Applied Economics. ISSN 1466-4283 DOI: https://doi.org/10.1080/00036846.2019.1693700

Link to Leeds Beckett Repository record:

https://eprints.leedsbeckett.ac.uk/id/eprint/6341/

Document Version:

Article (Accepted Version)

The aim of the Leeds Beckett Repository is to provide open access to our research, as required by funder policies and permitted by publishers and copyright law.

The Leeds Beckett repository holds a wide range of publications, each of which has been checked for copyright and the relevant embargo period has been applied by the Research Services team.

We operate on a standard take-down policy. If you are the author or publisher of an output and you would like it removed from the repository, please contact us and we will investigate on a case-by-case basis.

Each thesis in the repository has been cleared where necessary by the author for third party copyright. If you would like a thesis to be removed from the repository or believe there is an issue with copyright, please contact us on openaccess@leedsbeckett.ac.uk and we will investigate on a case-by-case basis. 


\title{
Asymmetric J-curve: Evidence from Industry Trade between U.S. and U.K.
}

\author{
Mohsen Bahmani-Oskooee* \\ Department of Economics \\ The University of Wisconsin-Milwaukee \\ Milwaukee, WI 53201 \\ bahmani@uwm.edu \\ and \\ Economics, Analytics \& International Business Group \\ Leeds Business School \\ Leeds Beckett University \\ m.a.nasir@leedsbeckett.ac.uk
}

Previous research that assessed the impact of exchange rate changes on the trade balance between the U.S. and U.K. assumed the effects are symmetric. In this paper we add to the literature on the asymmetric J-curve phenomenon by considering the trade balance of 68 two-digit industries that trade between the two countries. We find short-run asymmetric effects of the real dollar-pound rate in almost all industries. However, short-run asymmetric effects were translated into significant long-run asymmetric effects in 25 industries. Indeed, the asymmetric J-curve hypothesis was supported in 18 industries.

JEL Classification: F31

Key Words: J-Curve, the U.S., U. K., 68 Industries, Asymmetry Analysis

*. Valuable comments of three anonymous referees are greatly appreciated. Any remaining error, however, is ours. Corresponding author: M. Bahmani-Oskooee (bahmani@uwm.edu). 


\section{Introduction}

A country that experiences deterioration in its trade balance may adhere to currency depreciation. However, due to adjustment lags, the effects of a depreciation are not immediate. Indeed, the trade balance still continues to deteriorate and improves only when lags are realized, hence the J-curve pattern. This concept was introduced by Magee (1973) theoretically, and tested by Bahmani-Oskooee (1985) empirically. When researchers found no support for the J-Curve pattern, they suspected aggregation bias in the data. While Rose and Yellen (1989) recommended using aggregate bilateral trade data between two countries, Bahmani-Oskooee and Ardalani (2006) and Bahmani-Oskooee and Wang (2007) emphasized using trade flows between two countries based on commodity-level data. ${ }^{1}$

As far as our country of concern, the U.K., is concerned, a few studies have considered the British trade balance with the rest of the world and have reported mixed results. While Miles (1979) found adverse effects of depreciation of the British pound on the U.K.'s trade balance with the rest of the world, Himarios (1989) reported opposite results. However, both studies suffer from the problem of spurious regression, since neither of them engaged in unit root testing nor cointegration analysis. Once Rose (1991), Bahmani-Oskooee and Alse (1994), and Boyd et al. (2001) addressed such issues, they found no link between the British trade balance and the value of the pound.

The efforts by Rose and Yellen (1989) and Bahmani-Oskooee and Brooks (1999) to discover some significant link between the trade balance of the U.K. and that of its major partners, especially the U.S., was futile. However, when Bahmani-Oskooee and Kovyryalova (2008) disaggregated trade flows between the U.S. and U.K. by industry, they found significant short-run

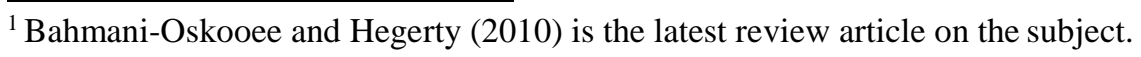


effects of the real dollar-pound rate on the trade balance of 107 of 177 industries and favorable longrun effects in 66 of 177 industries, therefore in support of the J-curve effect in 66 industries as well as support for disaggregation by commodity.

All studies reviewed above have assumed that the response of trade balance to exchange rate changes is symmetric, meaning that if $\mathrm{x} \%$ depreciation improves the trade balance by $\mathrm{y} \%$, then $\mathrm{x} \%$ appreciation will worsen the trade balance by $\mathrm{y} \%$. However, recent studies argue and demonstrate that the effects of exchange rate changes on the trade balance could be asymmetric. Bussiere (2013) demonstrated that import and export prices react to exchange rate movements in an asymmetric fashion. Bahmani-Oskooee and Fariditavana (2016) then argued that if traded goods' prices respond to exchange rate changes asymmetrically, then so should the trade volumes, and eventually the trade balance. They also argued that an asymmetric response could be due to change in traders' expectations with regards to a depreciation versus an appreciation. Finally, Arize et al. (2017) argued that trade could be subject to hysteresis which implies that if firms do not exit the market during currency appreciation, their export earnings will decline at a different rate than they would increase when currency depreciates, hence asymmetric effects.

The main purpose of this paper is to revisit the trade balance between the U.K. and the U.S. and try to determine the asymmetric response of the trade balance of each of the 68 two-digit industries to changes in the real dollar-pound rate. To that end, we introduce the models and methods in Section II, followed by our empirical results in Section III. A summary is then provided in Section IV, followed by an Appendix in which the sources of the data and definitions of variables are outlined. In order to gain some insight into the movement of the real dollar-pound rate, we plot it over our study period in Figure 1.

Figure 1 goes about here 


\section{The Models and Methods}

Since the method (conducted by prior research) of assessing the symmetric effects of exchange rate changes on trade balance relied upon a reduced-form trade balance model, asymmetry analysis has followed the same path. As such, in both approaches researchers have identified the level of economic activity in each of two trading partners and the real bilateral exchange rate as three main determinants of the trade balance. The theoretical model developed by Rose and Yellen (1989), and conformed to commodity-level data by Bahmani-Oskooee and Kovyryalova (2008), is adopted here as follows:

$$
\operatorname{LnTB} B_{i, t}=a+b \operatorname{Ln} Y_{U S, t}+c \operatorname{Ln} Y_{U K, t}+d \operatorname{Ln} R E X_{\mathrm{t}}+\varepsilon
$$

Since the data-reporting country is the U.S., equation (1) is from the U.S. perspective. As such, $\mathrm{TB}_{\mathrm{i}}$ is defined as the U.S. trade balance of industry i. For sign consistency, we define it as the U.S. imports of commodity i from the U.K. over the U.S. exports of commodity i to the U.K. Defining the trade balance as a ratio enables us to specify the model in logarithmic form. Furthermore, the ratio is unit free (Bahmani-Oskooee 1991). Since an increase in the level of economic activity (Y $Y_{U S}$ and $\left.\mathrm{Y}_{\mathrm{UK}}\right)$ stimulates a country's imports, we expect an estimate of $\mathrm{b}$ to be positive and that of $\mathrm{c}$ to be negative. ${ }^{2}$ As the Appendix reveals, the real exchange rate, REX, is defined such that a decline reflects a real depreciation of the dollar, and if a real depreciation is to improve the trade balance of industry i (i.e., decrease its imports and increase its exports), an estimate of $\mathrm{d}$ is expected to be positive.

\footnotetext{
${ }^{2}$ Note that if economic growth is due to an increase in production of import-substitute goods, it is possible for an estimate of $b$ to be negative and that of $c$ to be positive since imports will decline as each economy grows (BahmaniOskooee 1986).
} 
The estimates discussed above are long-run estimates. In order to also assess the short-run effects of all exogenous variables, the next step is to express (1) in an error-correction modeling format as follows:

$$
\begin{aligned}
\Delta \operatorname{LnTB}_{i, t} & =\alpha+\sum_{j=1}^{n} \beta_{t-j} \Delta \operatorname{LnTB} B_{i, t-j}+\sum_{j=0}^{n} \delta_{t-j} \Delta \operatorname{Ln} Y_{U S, t-j}+\sum_{j=0}^{n} \gamma_{t-j} \Delta \operatorname{Ln} Y_{U K, t-j}+\sum_{j=0}^{n} \pi_{t-j} \Delta \operatorname{LnREX} X_{t-j} \\
& +\lambda_{1} \operatorname{LnTB}_{i, t-1}+\lambda_{2} \operatorname{Ln} Y_{U S, t-1}+\lambda_{3} \operatorname{Ln} Y_{U K, t-1}+\lambda_{4} \operatorname{LnREX}_{t-1}+\mu_{t}
\end{aligned}
$$

Error-correction models such as (2) are introduced by Pesaran et al. (2001), with an advantage over other methods in that the short-run and the long-run effects are estimated in one step by estimating (2). The short-run effects are reflected in the estimates of coefficients attached to the first-differenced variables and the long-run effects are obtained by normalizing estimates of $\lambda_{2}-$ $\lambda_{4}$ normalized on $\lambda_{1}$. For the normalized estimates to be meaningful, Pesaran et al. (2001) propose applying the $\mathrm{F}$ test to establish joint significance of lagged level variables as a sign of cointegration. However, they show that the F test in this context has a new distribution for which they tabulate new critical values that account for the degree of integration of the variables. Indeed, under this method variables could be a combination of $\mathrm{I}(0)$ and $\mathrm{I}(1)$ and since these are properties of almost all macro variables, there is no need for pre-unit root testing, which is another advantage of this method.

Estimates from (2) reflect symmetric effects of exogenous variables. Shin et al. (2014) modify (2) so that we can infer asymmetric effects. Following their approach, we first form $\triangle L n R E X$ which includes positive changes as a reflection of dollar appreciation and negative changes reflecting dollar depreciation. Then, using the partial sum approach, two new series are generated as follows: 


$$
\operatorname{POS}_{t}=\sum_{j=1}^{t} \max \left(\Delta \operatorname{LnREX}_{j}, 0\right), \quad N E G_{t}=\sum_{j=1}^{t} \min \left(\Delta \operatorname{LnREX_{j},0)}\right.
$$

where $P O S_{t}$ is the partial sum of positive changes and reflects only dollar appreciation. By the same token, the $N E G_{t}$ variable is the partial sum of negative changes and reflects only dollar depreciation. ${ }^{3}$ Once the $\operatorname{LnREX}$ is replaced by the two partial sum variables, we have:

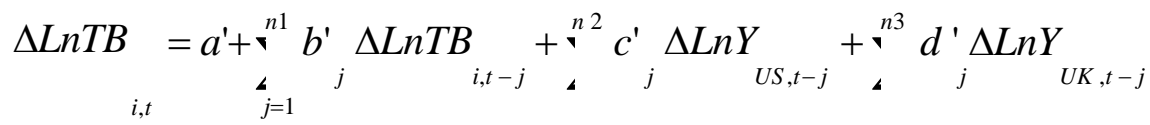

$$
\begin{aligned}
& +r^{n 4} e^{\prime} \Delta P O S \\
& { }_{j=0} \\
& +\theta_{2} L n Y_{U K, t-1}+\theta_{3} P O S_{t-1}+\theta_{4} N E G_{t-1}+
\end{aligned}
$$

Since constructing the partial sum variables introduces nonlinearity into (4), it is known as a nonlinear ARDL model, whereas (2) is called a linear ARDL model. Shin et al. (2014) demonstrate that both models are subject to the same estimation procedure and the same diagnostic tests. ${ }^{4}$

Once (4) is estimated, we can test a few asymmetry assumptions. If at any given lag order an estimate of e' is different than the estimate of $\mathrm{f}^{\prime}$, short-run asymmetric effects of dollar appreciation and dollar depreciation will be recognized. Furthermore, if the Wald test rejects the null of $\sum e^{\prime}=\sum f^{\prime}$, short-run cumulative or impact asymmetric effects will be established. On the other hand, long-run asymmetric effects will be recognized if the Wald test rejects the null of

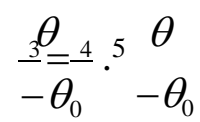

\footnotetext{
${ }^{3}$ Note that partial sum of positive (negative) changes is the same as cumulative sum where negative (positive) values are replaced by zeros.

${ }^{4}$ Shin et al. (2014, p. 291) argue that the two partial sum variables should be treated as a single variable so that the critical values of the F test could stay at conservative high level when we move from the linear to nonlinear model. ${ }^{5}$ For some other application of these and other nonlinear models see Delatte and Lopez-Villavicencio (2012), Bussiere (2013), Wimanda (2014), McFarlane et al. (2014), Gogas and Pragidis (2015), Durmaz (2015), Baghestani and Kherfi (2015), Al-Shayeb and Hatemi-J.(2016), Lima et al. (2016), Aftab et al. (2017), Gregoriou (2017), Nusair (2017), Olaniyi (2019), and Istiak and Alam (2019).
} 


\section{Empirical Results}

Since the late 1990s, the U.S. has begun reporting its trade statistics on a monthly basis and researchers have begun estimating their models using monthly data. Therefore, we estimate both the linear model (2) and the nonlinear model (4) for each of the 68 two-digit industries that trade between the U.S. and U.K. using monthly data over the period of January 1996 - April 2018. Since the data is monthly, in each model we impose a maximum of 10 lags on each first-differenced variable and use Akaike's Information Criterion (AIC) to select an optimal model. Since different estimates and diagnostic tests are subject to different critical values, we collect all required critical values in the notes to each table and use them to indicate if an estimate is significant at the $10 \%$ or $5 \%$ level. We use $*$ to indicate significance at the $10 \%$ level and $* *$ at the $5 \%$ level. We begin with the estimate of the linear model (2) and report the results in Tables 1-3.

From Table 1, which reports the short-run effects of the real dollar-pound rate, we gather that when the linear model is estimated using aggregate bilateral trade flows (coded by TB in the first row), the real exchange rate carries one significant coefficient. Since the coefficient is negative, dollar depreciation worsens the U.S. trade balance with U.K. in the short-run, consistent with the J-curve hypothesis. It also implies that dollar appreciation improves the trade balance in theshort run. Shortrun effects, however, do not last into the long-run because the normalized long-run coefficient

attached to LnREX in Table 2 is insignificant. However, when we consider the estimates for each industry, there are 35 industries in which there is at least one significant lagged coefficient. It appears that some industries even benefit from dollar depreciation since the estimate is positive (e.g. industry coded 00 or 02 ). Short-run effects last into significant long-run effects in 29 industries (Table 2). 
While in 16 industries the normalized long-run coefficient attached to LnREX is positive, in 13 industries it is negative. The 16 industries that will benefit from dollar depreciation in the long run are coded as $00,01,02,03,04,05,22,28,55,58,63,78,81,87,88$, and 96 . While most of these industries are small, one of the largest industries, 78 (Motor vehicles with $10.92 \%$ share of trade), is in the list. ${ }^{6}$ Such findings were absent from the estimates of the aggregate bilateral trade balance, which signifies the importance of disaggregation by industry.

The long-run estimates are valid since the F test for cointegration reported in Table 3 is significant. In some cases such as industry 41 (Animal oils and fats) in which the F test is insignificant but the exchange rate carries a significant coefficient, we can rely upon an alternative test known as the t-test or $\mathrm{ECM}_{\mathrm{t}-1}$ test for cointegration. Under this alternative test, we use normalized long-run coefficient estimates and long-run model (1) and generate the error term. Labeling this error term ECM, we consider the linear error-correction model (2) and replace the linear combination of lagged level variables by $\mathrm{ECM}_{\mathrm{t}-1}$ and estimate the new specification by imposing the same optimum lags. Cointegration will be supported if $\mathrm{ECM}_{\mathrm{t}-1}$ carries a significantly negative coefficient. ${ }^{7}$ Indeed, this is the case in most of the optimalmodels.

A few additional diagnostics are also reported in Table 3. To check for serial correlation and misspecification, we have reported the Lagrange Multiplier test statistic as LM and Ramsey's RESET test as RESET. Since both statistics are insignificant in almost all models, residuals in each optimal model are autocorrelation-free, meaning that these models are correctly specified. We have also applied the well-known CUSUM and CUSUMSQ to the residual of each optimal model to test the

\footnotetext{
${ }^{6}$ Note that the 13 industries in which the real bilateral exchange rate carries a negative coefficient are industries for which the import demands are inelastic (Bahmani-Oskooee and Aftab 2017, endnote 11).

${ }^{7}$ This test originally was introduced by Banerjee et al. (1998) within the Engle-Granger error-correction modeling framework. Pesaran et al. (2001) have incorporated the concept into the ARDL approach, and since we have a combination of $\mathrm{I}(0)$ and $\mathrm{I}(1)$ variables, as with the $\mathrm{F}$ test, they have tabulated new critical values for this t-test which we use in this paper. For cointegration, the calculated t-ratio must be greater than the upper-bound critical values.
} 
stability of short-run and long-run coefficient estimates. Stable estimates are indicated by "S" and unstable ones by "UNS". Clearly, all estimates are stable. Finally, the size of adjusted $\mathrm{R}^{2}$ is reported to judge the goodness of the fit in eachoptimal model.

In order to see how the results change if we consider the estimates of nonlinear models, we report them in Tables 4-7. While the short-run estimates are reported in Tables 4 and 5, long-run estimates are reported in Table 6 followed by diagnostics in Table 7. From Tables 4 and 5 we gather that either $\triangle \mathrm{POS}$ or $\triangle \mathrm{NEG}$ carry at least one significant coefficient in a total of 48 industries, supporting short-run effects of exchange rate changes on the trade balance of these industries. The increase in the number of cases from 35 in Table 1 (short-run estimates of the linear model) to 48 must be attributed to separating dollar appreciation from dollar depreciation and introducing the nonlinear adjustment of the real dollar-pound rate. Furthermore, at a given specific lag order $\mathrm{j}$, the coefficient attached to $\triangle \mathrm{POS}_{\mathrm{t}-\mathrm{j}}$ is different than the one attached to $\triangle \mathrm{NEG}_{\mathrm{t}-\mathrm{j}}$ for a majority of the $\mathrm{j}$ 's, supporting short-run asymmetric effects of dollar appreciation versus dollar depreciation. However, short-run cumulative or impact asymmetric effects is established only in 25 industries, since the Wald test reported as Wald-S in Table 7 is significant, rejecting the equality of the two sums. These 25 industries are coded as 00, 07, 09, 11, 29, 41, 42, 54, 57, 58, 64, 65, 66, 67, 68, 72, 73, 74, 77, 82, 83, $87,89,95$, and 97 . While many are small industries, several large industries are in the list. They are 11 (Beverages with 2.14\% share of trade), 54 (Medical Products with 6.96\% trade share), 72 (Machinery Specialized with 2.4\% trade share), 74 (General Industrial Machinery with $4.58 \%$ trade share), 77 (Electric Machinery with 3.84\% trade share), 87 (Professional Scientific Instruments with 3.56\% trade share), 89 (Miscellaneous Manufactured Articles with 8.21\% trade share), and 97 (Gold, Nonmonetary with $4.56 \%$ trade share). 
The short-run asymmetric effects last into the long run in 27 industries where, as Table 6 reveals, either the POS or the NEG variable carries a significant coefficient. The estimates are meaningful since either the $\mathrm{F}$ test or the $\mathrm{ECM}_{\mathrm{t}-1}$ test reported in Table 7 is significant, supporting asymmetry cointegration. Although the number of industries that are affected by exchange rate changes in the long run is almost the same as the estimates from the linear models, the nonlinear estimates reveal some interesting information that was masked by the linear models. First, dollar depreciation improves the trade balance of industries coded 00, 05, 11, 28, 55, 56, 58, 63, 64, 66, 73, 81, 84, and 93 since in these 14 industries, the NEG variable carries a significantly positive coefficient.

Since total share of trade by these industries is $13.45 \%$, we may conclude that dollar depreciation only helps $13.45 \%$ of the trade between the U.S. and the U.K. Second, due to inelastic import demands, dollar depreciation hurts the trade balance of industries coded as $09,21,51,59,71,77$, and 82 since the NEG variable carries a negative coefficient. The total share of trade by these industries is $13.82 \%$. Thus, dollar depreciation will hurt only $13.82 \%$ of the trade between these two countries. It appears that the amount of trade that benefits from dollar depreciation is almost the same as the amount that is hurt. This supports the insignificant coefficient attached to the NEG variable when the linear model is estimated using aggregate bilateral trade flows. Third, dollar appreciation hurts the trade balance of industries coded as $00,02,05,11,28,55,56,58,63,64,73,78,81,88,93$, and 96 since the POS variable carries a positive coefficient in these industries. These 16 industries engage in a total of $23.46 \%$ of the trade. Finally, again due to inelastic import demands, dollar appreciation improves the trade balance of $07,09,21,51,59,68,71,74$, and 77 which altogether engage in $19.12 \%$ of the trade. Such findings point at long-run asymmetric effects of dollar depreciation versus dollar appreciation and are supported by the significant Wald test reported as Wald-L in Table 7 in a total of 52 industries. 
Putting the industries together from the first group and the third group, the asymmetry J-curve hypothesis introduced by Bahmani-Oskooee and Fariditavana (2016) is supported in a total of 18 industries. The list includes $00,02,05,11,28,55,56,58,63,64,66,73,78,81,84,88,93$, and 96. These are the industries in which both the NEG and POS variables carry a significantly-positive coefficient. Although the nonlinear model did not yield strongly surprising outcomes, it at least identified industries that could benefit from, or be hurt by, changes (in either direction) in the real dollar-pound rate, which could be a good source of information for eachindustry. ${ }^{8}$

\section{Summary and Conclusion}

Since the introduction of asymmetry cointegration and asymmetry error-correction modeling by Shin et al. (2014), the link between the real exchange rate and the trade balance summarized by the J-curve phenomenon has received renewed attention. Indeed, asymmetry analysis, which requires using nonlinear models, separates currency depreciations from appreciations and reveals interesting information that could be masked by symmetry analysis and linear models. While Rose and Yellen (1989) used symmetry analysis and linear models to define the J-curve hypothesis as short-run deterioration combined with long-run improvement, Bahmani-Oskooee and Fariditavana (2016) introduced the concept of asymmetric J-curve in which a depreciation improves the trade balance and an appreciation has no effect, or an appreciation hurts the trade balance and a depreciation has no effect.

In this paper we add to the new literature by considering the trade balance between the U.S. and the U.K.. When we estimated a bilateral trade balance model, we were unable to find any significant link between the two variables either by the linear or nonlinear model. However, when we disaggregated the trade flows between the two countries by industry and estimated both models for

\footnotetext{
${ }^{8}$ Note that other diagnostic statistics are similar to those of the linear models and no need to review them again.
} 
each of the 68 two-digit industries, we were able to discover some significant and interesting outcomes. Our findings could be best summarized by saying that when the linear trade balance model was estimated for each industry, we found significant short-run effects of the real dollar-pound rate on the trade balance of 35 industries. Short-run effects lasted into long run significant effects in 29 industries, but only in 16 industries was the symmetry J-curve hypothesis supported. The corresponding numbers were somewhat higher when we estimated the nonlinear models. Indeed, nonlinear models revealed that the exchange rate changes have significant short-run effects on the trade balance of 48 industries. While short-run effects were asymmetric in all industries, short-run cumulative asymmetric effects were established in 25 industries. However, short-run asymmetric effects lasted into significant long-run asymmetric effects in 52 industries.

Since dollar depreciations are separated from dollar appreciations in nonlinear models, additional analysis helped us to identify U.S. industries that benefit from dollar depreciations and those that benefit from dollar appreciations (due to inelastic imports demands). Similarly, we were able to identify industries that are hurt by dollar appreciations and those that benefit from dollar appreciation (again, due to inelastic import demand). 


\section{APPENDIX}

\section{Data Definition and Source}

Monthly data over the period January 1996 - April 2018 are used in the empirical analysis. The data come from the following sources:
A. US trade online (https://usatrade.census.gov)
B. International Financial statistics (IFS)

\section{Variables:}

$T B_{i}=$ US trade balance with UK for commodity ' $\mathrm{i}$ ' defined as US imports of commodity ' $\mathrm{i}$ ' from UK divided by US exports of commodity 'i' to UK [Source:A].

$Y_{U K}=\mathrm{UK}$ 's aggregate output as measured by an index of industrial production. [Source:B].

$\mathrm{Y}_{\mathrm{US}}=\mathrm{US}$ aggregate output as measured by an index of industrial production. [Source:B].

$R E X=$ The real bilateral exchange rate of the US dollar against Pounds. It is defined as $R E X=\left(P_{U S}\right.$. $\left.N E X / P_{U K}\right)$ where $N E X$ is the nominal exchange rate defined as number of Pound per USD. Thus, a decline in REX reflects a real depreciation of the USD. Both price levels are measured by CPI. All data come from source B.

\section{Figure 1: Plot of the Real Dollar-Pound Rate}

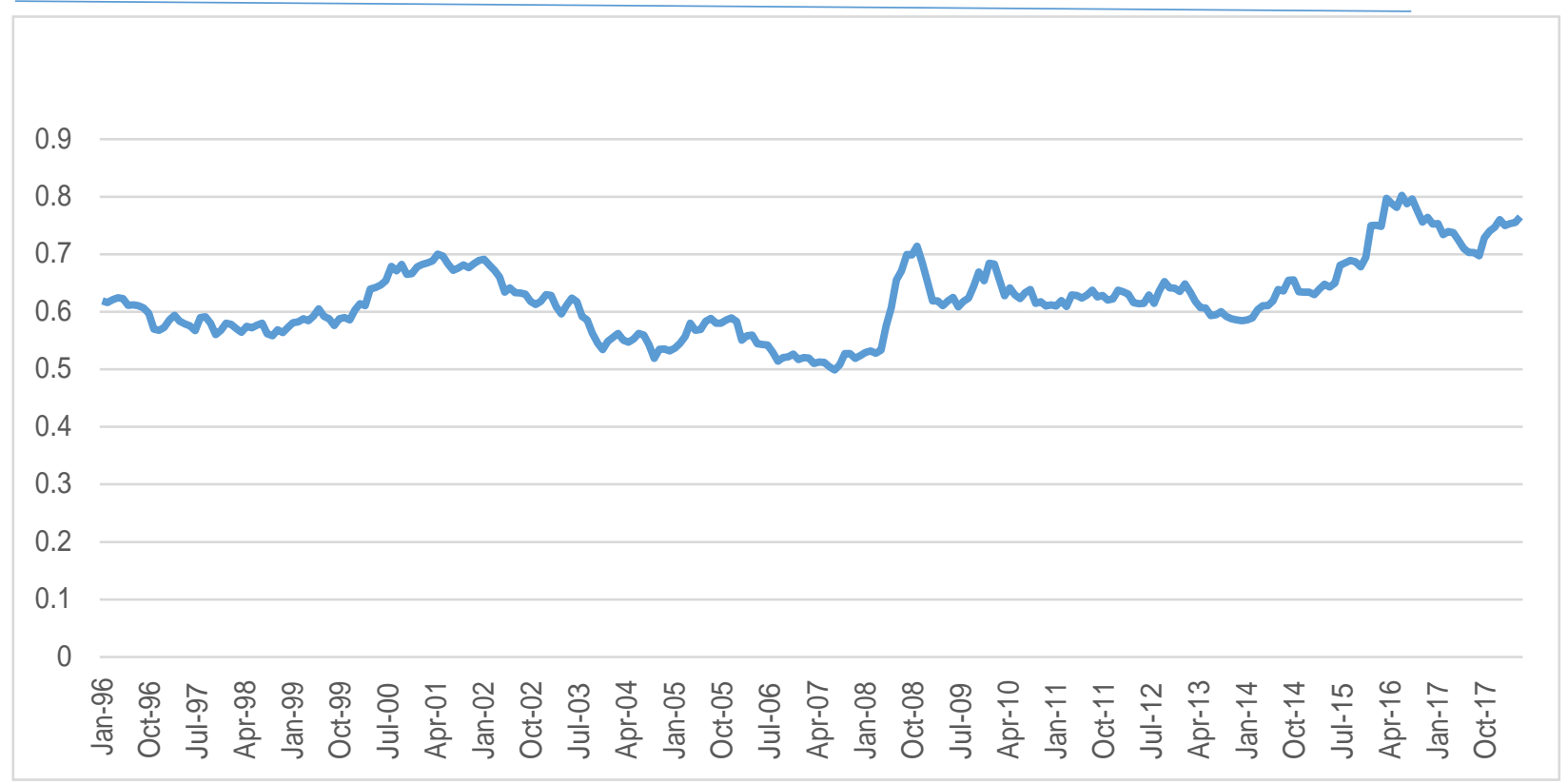

Note: A decline reflects a real depreciation of the dollar. 
It must be noted that following a referendum on June 2016, the UK government formally announced the country's withdrawal from EU. After the announcement, the pound lost its value against major currencies such as the dollar, as seen in Figure 1. However, since the withdrawal has not been settled, the pound has gained back some of the losses. Could our results be affected by this event? Perhaps not since most of the observations in our study period belong to pre-Brexit referendum period. However, we tested our conjecture by including a dummy in the models to account for this event. Our effort was futile in that the dummy was insignificant, as expected. 


\section{References}

Aftab, M., K.B.S. Syed, and N. A. Katper, (2017) "Exchange-rate volatility and MalaysianThai bilateral industry trade flows", Journal of Economic Studies, Vol. 44, pp.99-114.

Al-Shayeb, A. and A.Hatemi-J., (2016) "Trade openness and economic development in the UAE: an asymmetric approach", Journal of Economic Studies, Vol. 43, pp.587-597.

Arize, A. C., J. Malindretos, and E.U. Igwe, (2017), "Do Exchange Rate Changes Improve the Trade Balance: An Asymmetric Nonlinear Cointegration Approach", International Review of Economics and Finance, Vol. 49, pp. 313-326.

Baghestani, H. and S. Kherfi, (2015) "An error-correction modeling of US consumer spending: are there asymmetries?", Journal of Economic Studies, Vol. 42, pp.1078-1094.

Bahmani-Oskooee, M. (1985), "Devaluation and the J-Curve: Some Evidence from LDCs,"The Review of Economics and Statistics, Vol. 67, August, pp. 500-504.

Bahmani-Oskooee, M. (1986): "Determination of International Trade Flows: The Case of Developing Countries", Journal of Development Economics, 20, 107-123.

Bahmani-Oskooee, M. (1991): "Is there a Long Run Relation Between the Trade Balance and the Real Effective Exchange Rate of LDCs?", Economics Letters, 36, 403-407.

Bahmani-Oskooee, M. and Alse, J., (1994) "Short-Run Versus Long-Run Effects of Devaluation: Error Correction Modeling and Cointegration”, Eastern Economic Journal, Fall, 20(4), Pp. 45364.

Bahmani-Oskooee, Mohsen and Brooks, Taggert J., (1999) "Bilateral J-Curve Between U.S. and her Trading Partners”, Weltwirtschaftliches Archiv, Vol. 135, pp. 156-165.

Bahmani-Oskooee, M. and M. Kovyryalova (2008), "The J-Curve: Evidence from Industry Trade Data between U.S. and U.K.”, Economic Issues, Vol. 13, pp. 25-44.

Bahmani-Oskooee, M. and Z. Ardalani (2006), "Exchange Rate Sensitivity of U.S. TradeFlows: Evidence from Industry Data", Southern Economic Journal, Vol. 72, pp. 542-559.

Bahmani-Oskooee, M. and Y. Wang (2007), "U.S.-China Trade at the Commodity Level and the Yuan-Dollar Exchange Rate”, Contemporary Economic Policy, Vol. 25, pp.341-161.

Bahmani-Oskooee, M. and S. Hegerty (2010), "The J- and S-Curves: A Survey of the Recent Literature", Journal of Economic Studies, Vol. 37, pp. 580-596.

Bahmani-Oskooee, M. and H. Fariditavana (2016), "Nonlinear ARDL Approach and the JCurve Phenomenon", Open Economies Review, Vol. 27, pp. 51-70. 
Bahmani-Oskooee, M. and M. Aftab (2017), "Asymmetric Effects of Exchange Rate Changes and the J-Curve: New Evidence from Malaysia-Thailand 61 Industry Trade", Review of Development Economics, Vol. 21, pp. 30-46.

Banerjee, A., J. Dolado, and R. Mestre (1998), "Error-Correction Mechanism Tests in a Single Equation Framework," Journal of Time Series Analysis, 19, 267-85.

Boyd, D., G. M. Caporale and R. Smith, 2001, "Real Exchange Rate Effects on the Balance of Trade: Cointegration and Marshall-Lerner Condition”, International Journal of Finance and Economics, Vol. 6, pp. 187-200.

Bussiere, M. (2013), "Exchange rate Pass-through to Trade Prices: The Role of Nonlinearities and Asymmetries", Oxford Bulletin of Economics and Statistics, Vol. 75, pp. 731-758.

Delatte, Anne-Laure and Antonio Lopez-Villavicencio (2012), “Asymmetry Exchange Rate Pass-Through: Evidence from Major Countries", Journal of Macroeconomics, 34, 833-844.

Durmaz, N. (2015), “Industry Level J-Curve in Turkey,” Journal of Economic Studies, Vol. 42, pp. 689-706.

Gogas, P. and I. Pragidis, (2015) "Are there asymmetries in fiscal policy hocks?", Journal of Economic Studies, Vol. 42, pp.303-321.

Gregoriou, A. (2017) "Modelling non-linear behaviour of block price deviations when trades are executed outside the bid-ask quotes.", Journal of Economic Studies, Vol. 44, pp. 206-213.

Halicioglu, F., (2007): “The J-Curve Dynamics of Turkish Bilateral Trade: A Cointegration Approach", Journal of Economic Studies, 34, 103-119.

Istiak, K. and M. R. Alam (2019), "Oil prices, policy uncertainty and asymmetries in inflation expectations”, Journal of Economic Studies, Vol. 46, pp. 324-334.

Himarios, D. (1989), "Do Devaluations improve the Trade Balance? The Evidence Revisited", Economic Enquiry, 27, pp 143-168.

Lima, L., C. Foffano Vasconcelos, J. Simão, and H. de Mendonça, (2016) "The quantitative easing effect on the stock market of the USA, the UK and Japan: An ARDL approach for the crisis period", Journal of Economic Studies, Vol. 43, pp.1006-1021.

McFarlane, A., A. Das, M. Chowdhury, (2014) "Non-linear dynamics of employment, output and real wages in Canada: Recent time series evidence", Journal of Economic Studies, Vol. 41, pp.554-568.

Magee, Stephen P. (1973), “Currency Contracts, Pass Through and Devaluation”, Brooking Papers on Economic Activity, 1, pp. 303-325. 
Miles, Marc A., (1979), "The Effects of Devaluation on the Trade Balance and the Balance of Payments: Some New Results", Journal of Political Economy, Vol. 87, pp. 600-619.

Nusair, Salah A. (2017), “The J-curve Phenomenon in European Transition Economies: A Nonliear ARDL Approach”, International Review of Applied Economics, Vol. 31, 1-27

Olaniyi, C. (2019), "Asymmetric information phenomenon in the link between CEO pay and firm performance: An innovative approach", Journal of Economic Studies, Vol. 46, pp. 306 $-323$.

Pesaran, M. H., Y. Shin, and Smith, R. J. (2001), "Bounds Testing Approaches to the Analysis of Level Relationships," Journal of Applied Econometrics, Vol. 16, pp. 289-326.

Rose, Andrew K., (1991), "The Rose of Exchange Rates in a Popular Model of International Trade: Does the 'Marshall-Lerner' Condition Hold?", Journal of International Economics, Vol. 30, pp. 301-316.

Rose, Andrew K. and Yellen, Janet L. (1989), “Is There a J-Curve?” Journal of Monetary Economics, Vol. 24, July, pp. 53-68.

Shin, Y, B. C. Yu, and M. Greenwood-Nimmo (2014) "Modelling Asymmetric Cointegration and Dynamic Multipliers in a Nonlinear ARDL Framework" Festschrift in Honor of Peter Schmidt: Econometric Methods and Applications, eds. by R. Sickels and W. Horrace: Springer, 281-314.

Wimanda, R. E. (2014), "Threshold effects of inflation: Evidence from Indonesia”, Journal of Economic Studies, Vol. 42, pp. 196 215. 
Table 1: Short-Run Coefficient Estimates of Linear ARDL Model (2)

\begin{tabular}{|c|c|c|c|c|c|c|c|c|c|c|}
\hline \multirow{2}{*}{ Code } & \multicolumn{10}{|c|}{ Short-Run Coefficient Estimates } \\
\hline & $\Delta \operatorname{Ln} R E X_{t}$ & $\Delta \operatorname{Ln} R E X_{t-1}$ & $\Delta$ LnREX $_{t-2}$ & $\Delta \operatorname{Ln} R E X_{t-3}$ & $\Delta$ LnREX $_{t-4}$ & $\Delta$ LnREX $_{t-5}$ & $\Delta$ LnREX $_{t-6}$ & $\Delta$ LnREX $_{t-7}$ & $\Delta \operatorname{LnREX}_{t-8}$ & $\triangle$ LnREX $_{t-9}$ \\
\hline TB & $-0.67(2.07)^{* *}$ & & & & & & & & & \\
\hline 00 & $1.78(1.84)^{*}$ & & & & & & & & & \\
\hline 01 & $-2.48(1.22)$ & & & & & & & & & \\
\hline 02 & $1.13(2.50)^{* *}$ & & & & & & & & & \\
\hline 03 & $0.53(1.97) * *$ & & & & & & & & & \\
\hline 04 & $0.91(0.60)$ & & & & & & & & & \\
\hline 05 & $0.45(1.85)^{*}$ & & & & & & & & & \\
\hline 06 & $-3.87(2.04)^{* *}$ & $4.73(2.47)^{* *}$ & & & & & & & & \\
\hline 07 & $-0.37(0.24)$ & $3.38(2.11)^{* *}$ & $-1.93(1.20)$ & $0.59(0.36)$ & $3.38(2.10)^{* *}$ & & & & & \\
\hline 08 & $-0.37(0.50)$ & & & & & & & & & \\
\hline 09 & $-2.19(2.47)^{* *}$ & & & & & & & & & \\
\hline 11 & $1.56(1.92)^{*}$ & $-0.56(0.69)$ & $1.91(2.33)^{* *}$ & & & & & & & \\
\hline 12 & $-1.46(1.50)$ & & & & & & & & & \\
\hline 21 & $-1.08(0.88)$ & & & & & & & & & \\
\hline 22 & $0.12(0.02)$ & & & & & & & & & \\
\hline 23 & $-0.17(0.53)$ & & & & & & & & & \\
\hline 24 & $0.04(0.07)$ & & & & & & & & & \\
\hline 25 & $10.05(1.64)^{*}$ & $-14.35(2.1)^{* *}$ & & & & & & & & \\
\hline 26 & $0.08(0.25)$ & & & & & & & & & \\
\hline 27 & $-0.34(1.25)$ & & & & & & & & & \\
\hline 28 & $0.94(2.05) * *$ & & & & & & & & & \\
\hline 29 & $-2.66(2.00) * *$ & & & & & & & & & \\
\hline 32 & $0.042(0.01)$ & & & & & & & & & \\
\hline 33 & $-1.45(2.08)^{* *}$ & & & & & & & & & \\
\hline 34 & $-25.18(0.48)$ & $6.84(0.15)$ & $-53.85(1.14)$ & $16.39(0.38)$ & $25.53(0.48)$ & & & & & \\
\hline 41 & $-2.18(1.71)^{*}$ & & & & & & & & & \\
\hline 42 & $-0.82(1.17)$ & & & & & & & & & \\
\hline 43 & $-1.36(1.02)$ & & & & & & & & & \\
\hline 51 & $-0.51(1.37)$ & & & & & & & & & \\
\hline 52 & $-1.003(1.60)$ & & & & & & & & & \\
\hline 53 & $-0.068(0.486)$ & & & & & & & & & \\
\hline 54 & $-1.55(1.73)^{*}$ & $-1.07(1.17)$ & $1.80(1.95)^{*}$ & & & & & & & \\
\hline
\end{tabular}




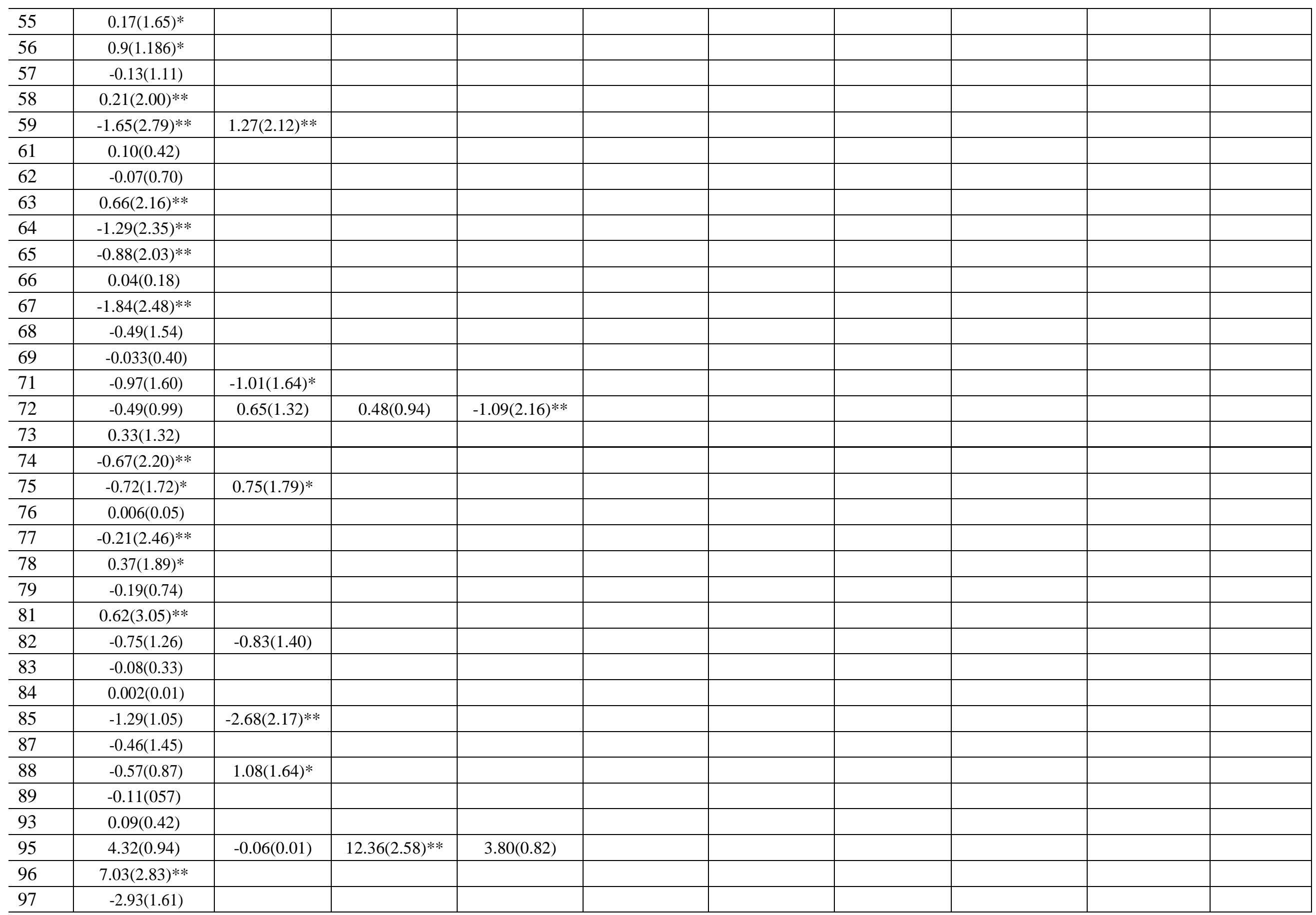




\begin{tabular}{l|c|c|c|c|l|l|l|l|l|}
\hline 98 & $-0.36(1.02)$ & $-0.58(1.63)$ & $0.67(1.88)^{*}$ & $-0.57(1.58)$ & & & & & \\
\hline 99 & $0.06(0.96)$ & & & & & & & & \\
\hline
\end{tabular}

Notes: Numbers inside parentheses are absolute values of the t-ratios. The critical value of standard t-ratio is $1.64(1.96)$ at the $10 \%(5 \%)$ significance level. * (**) indicate 4 significance at the $10 \%(5 \%)$ level. 
Table 2: Long-Run Coefficient Estimates of Linear ARDL Model (2)

\begin{tabular}{|c|c|c|c|c|c|}
\hline \multirow{2}{*}{ Industries } & \multirow[b]{2}{*}{ Trade Share } & \multicolumn{4}{|c|}{ Long-Run Coefficient Estimates } \\
\hline & & Constant & $\operatorname{Ln} Y_{U S}$ & $\operatorname{Ln} Y_{U K}$ & Ln REX \\
\hline TB (US- UK Trade Balance Aggregate) & $100 \%$ & $-5.85(1.45)$ & $0.47(1.01)$ & $0.76(1.31)$ & $-0.28(0.96)$ \\
\hline 00 Live Animals & $0.18 \%$ & $-24.46(2.20)^{* *}$ & $-1.14(0.95)$ & $6.54(3.60) * *$ & $1.72(1.95)^{* *}$ \\
\hline 01 Meat \& Meat Preparations & $0.05 \%$ & $36.68(1.71)^{*}$ & $0.99(0.57)$ & $-8.41(2.27)^{* *}$ & $4.70(3.04)^{* *}$ \\
\hline 02 Dairy Products and Birds Eggs & $0.08 \%$ & $20.98(1.98)^{* *}$ & $-0.23(0.20)$ & $-3.86(2.42)^{* *}$ & $2.21(3.22)^{* *}$ \\
\hline 03 Fish (Except Marine Mammal) & $0.22 \%$ & $4.28(0.45)$ & $3.69(3.87)^{* *}$ & $-4.45(2.75) * *$ & $1.62(1.96)^{* *}$ \\
\hline 04 Cereals And Cereal Preparation & $0.18 \%$ & $2.45(0.39)$ & $2.47(3.99)^{* *}$ & $-2.91(3.07)^{* *}$ & $1.074(2.36)^{* * *}$ \\
\hline 05 Vegetables and Fruits & $0.35 \%$ & $5.10(0.80)$ & $1.55(2.20)^{* *}$ & $-3.24(3.33)^{* *}$ & $0.94(2.21)^{* *}$ \\
\hline 06 Sugars, Sugar Preparations & $0.03 \%$ & $-4.26(0.15)$ & $-11.06(3.76)^{* *}$ & $12.16(2.84)^{* *}$ & $1.24(0.58)$ \\
\hline 07 Coffee, Tea, Cocoa & $0.09 \%$ & $-13.40(1.62)$ & $-5.09(5.20)^{* *}$ & $7.90(5.92)^{* *}$ & $-2.48(3.35) * *$ \\
\hline 08 Feeding Stuff For Animals & $0.14 \%$ & $-90.28(0.74)$ & $12.22(2.57)^{* *}$ & $6.65(0.73)$ & $-2.08(0.50)$ \\
\hline 09 Miscellaneous Edible & $0.29 \%$ & $36.53(8.70)^{* *}$ & $-1.97(3.99)^{* *}$ & $-6.10(9.75)^{* *}$ & $-0.70(2.50)^{* * *}$ \\
\hline 11 Beverages & $2.14 \%$ & $8.60(2.71)^{* *}$ & $-0.48(1.54)$ & $-1.036(1.96)^{* *}$ & $0.34(1.36)$ \\
\hline 12 Tobacco and Tobacco & $0.004 \%$ & $-51.7(2.14)^{* *}$ & $8.31(3.90)^{* *}$ & $2.71(0.67)$ & $-2.62(1.40)$ \\
\hline 21 Hides, Skins and Fur-skins & $0.002 \%$ & $-58.43(2.25)^{* *}$ & $2.93(1.11)$ & $9.09(2.17)^{* *}$ & $-1.51(0.98)$ \\
\hline 22 Oil Seeds and Oleaginous & $0.10 \%$ & $-60.89(1.40)$ & $4.39(0.75)$ & $8.27(1.15)$ & $4.25(1.76)^{* * *}$ \\
\hline 23 Crude Rubber & $0.07 \%$ & $24.61(1.17)$ & $-1.74(0.75)$ & $-3.82(1.24)$ & $-0.78(0.54)$ \\
\hline 24 Cork and Wood & $0.56 \%$ & $-84.59(3.20)^{* *}$ & $-7.64(2.96)^{* *}$ & $24.75(2.28)^{* *}$ & $0.13(0.06)$ \\
\hline 25 Pulp and Waste Paper & $0.01 \%$ & $-3134.30(0.08)$ & $221.19(0.08)$ & 475.64(0.08) & $232.31(0.08)$ \\
\hline 26 Textile Fibers & $0.03 \%$ & $-50.69(3.13)^{* *}$ & $0.88(0.50)$ & $10.08(3.99)^{* *}$ & $0.33(0.26)$ \\
\hline 27 Crude Fertilizers & $0.06 \%$ & $-10.67(1.24)$ & $0.34(0.43)$ & $1.64(1.08)$ & $-0.85(1.14)$ \\
\hline 28 Metalliferous Ores & $1.07 \%$ & $-11.72(0.70)$ & $-1.15(0.70)$ & $3.67(1.40)$ & $2.81(2.25) * *$ \\
\hline 29 Crude Animal and Vegetable Materials & $0.07 \%$ & $-5.72(1.02)$ & $-1.34(2.47)^{* *}$ & $2.29(2.44) * *$ & $-0.80(1.80) *$ \\
\hline 32 Coal, Coke and Briquettes & $0.29 \%$ & $100.73(1.38)$ & $-8.01(0.73)$ & $-14.73(1.33)$ & $0.07(0.01)$ \\
\hline 33 Petroleum, Petroleum Products & $7.57 \%$ & $-31.11(1.51)$ & $-6.41(2.82)^{* *}$ & $13.26(4.20)^{* *}$ & $-4.07(2.40)^{* * *}$ \\
\hline 34 Gas, Natural and Manufactured & $0.30 \%$ & $143.60(0.43)$ & $-26.07(1.08)$ & $-6.20(0.11)$ & $-13.58(0.78)$ \\
\hline 41 Animal Oils and Fats & $0.02 \%$ & $-60.61(0.78)$ & $-1.82(0.19)$ & $14.08(1.46)$ & $-9.40(2.07) * *$ \\
\hline 42 Fixed Veg. Fats \& Oils & $0.01 \%$ & $-6.73(0.39)$ & $0.57(0.27)$ & $0.78(0.32)$ & $-1.54(1.27)$ \\
\hline 43 Animal/Veg Fats/Oils Process/Waste & $0.02 \%$ & $16.02(0.18)$ & $-0.71(0.08)$ & $-4.02(0.29)$ & $-8.25(1.03)$ \\
\hline 51 Organic Chemicals & $2.51 \%$ & $5.56(0.44)$ & $-0.53(0.43)$ & $-0.54(0.26)$ & $-1.39(1.38)$ \\
\hline 52 Inorganic Chemicals & $0.42 \%$ & $9.44(0.68)$ & $0.69(0.46)$ & $-2.83(1.29)$ & $-2.12(1.77)^{*}$ \\
\hline 53 Dyeing, Tanning and Coloring Materials & $0.24 \%$ & $-5.87(1.42)$ & $0.023(0.06)$ & $1.27(1.86)^{*}$ & $-0.16(0.47)$ \\
\hline 54 Medicinal and Pharmaceutical Products & $6.96 \%$ & $-8.18(0.95)$ & $-0.57(0.69)$ & $2.39(1.78)^{*}$ & $-0.34(0.52)$ \\
\hline
\end{tabular}




\begin{tabular}{|c|c|c|c|c|c|}
\hline 55 Essential Oils & $1.28 \%$ & $-4.70(0.90)$ & $0.11(0.19)$ & $0.91(1.10)$ & $0.76(1.98)^{* * *}$ \\
\hline 56 Fertilizers & $0.02 \%$ & $-22.41(2.06)^{* *}$ & $2.80(2.64) * *$ & $2.17(1.06)$ & $1.17(1.33)$ \\
\hline 57 Plastics in Primary Form & $0.57 \%$ & $5.30(1.96)^{* *}$ & $-0.02(0.08)$ & $-1.22(2.57)^{* *}$ & $-0.24(1.10)$ \\
\hline 58 Plastics in Non-primary Form & $0.64 \%$ & $0.12(0.04)$ & $-0.19(0.52)$ & $0.17(0.34)$ & $0.56(2.55)^{* *}$ \\
\hline 59 Chemical Materials & $1.58 \%$ & $-0.05(0.01)$ & $1.13(2.19)^{* *}$ & $-1.15(1.78)^{* *}$ & $-0.43(1.26)$ \\
\hline 61 Leather, Leather MFR & $0.04 \%$ & $-6.71(0.79)$ & $-0.49(0.57)$ & $2.22(1.52)$ & $0.31(0.44)$ \\
\hline 62 Rubber Manufactures & $0.38 \%$ & $-1.59(0.10)$ & $-0.65(0.41)$ & $1.06(0.46)$ & $-0.65(0.60)$ \\
\hline 63 Cork and Wood Manufactures & $0.09 \%$ & $-45.89(6.06)^{* *}$ & $0.17(0.22)$ & $9.37(8.26)^{* *}$ & $1.48(2.42) * *$ \\
\hline 64 Paper, Paperboard & $0.52 \%$ & $-19.94(5.15)^{* *}$ & $-0.11(0.26)$ & $4.40(7.17)^{* *}$ & $0.30(1.02)$ \\
\hline 65 Textile Yarn, Fabrics & $0.44 \%$ & $-15.26(3.01)^{* *}$ & $0.91(1.62)$ & $2.36(3.00)^{* *}$ & $-0.30(0.76)$ \\
\hline 66 Nonmetallic Mineral & $1.13 \%$ & $-0.82(0.04)$ & $-4.99(2.60) * *$ & $5.13(1.77)^{*}$ & $0.24(0.18)$ \\
\hline 67 Iron and Steel & $0.59 \%$ & $-0.99(0.16)$ & $-0.02(0.03)$ & $0.39(0.39)$ & $-0.87(1.87)^{*}$ \\
\hline 68 Nonferrous Metals & $1.40 \%$ & $-26.46(2.55)^{* *}$ & $2.17(1.84)^{*}$ & $3.47(2.13)^{* *}$ & $-1.26(1.75)^{*}$ \\
\hline 69 Manufactures of Metals & $1.45 \%$ & $-2.23(1.34)$ & $-0.66(3.83)^{* *}$ & $1.07(3.90)^{* *}$ & $-0.057(0.41)$ \\
\hline 71 Power Generating Machinery & $4.83 \%$ & $9.13(1.31)$ & $1.77(2.48)^{* *}$ & $-3.67(3.29)^{* *}$ & $-0.97(2.09)^{* *}$ \\
\hline 72 Machinery Specialised & $2.40 \%$ & $10.52(1.50)$ & $0.52(0.70)$ & $-2.74(2.66)^{* *}$ & $-0.19(0.30)$ \\
\hline 73 Metalworking Machinery & $0.28 \%$ & $-1.86(0.22)$ & $-0.68(0.86)$ & 1.158837 & $0.95(1.39)$ \\
\hline 74 General Industrial Machinery & $5.58 \%$ & $3.41(0.72)$ & $-0.25(0.438)$ & $-0.50(0.75)$ & $-0.52(1.49)$ \\
\hline 75 Office Machines and ADP Equipment & $1.47 \%$ & $-1.01(0.25)$ & $-1.26(3.11)^{* *}$ & $1.29(1.92)^{* *}$ & $0.26(0.89)$ \\
\hline 76 Telecommunications Equipment & $1.64 \%$ & $-10.10(3.17)^{* *}$ & $1.16(3.32)^{* *}$ & $0.87(1.69)^{*}$ & $0.014(0.05)$ \\
\hline 77 Electrical Machinery, Apparatus \& Appliances & $3.84 \%$ & $5.87(1.87)^{*}$ & $1.24(4.05)^{* *}$ & $-2.64(5.02) * *$ & $-0.63(2.54)^{* *}$ \\
\hline 78 Motor Vehicles & $10.92 \%$ & $-12.25(1.88)^{*}$ & $0.80(1.18)$ & $2.19(2.12)^{* *}$ & $0.98(1.88)^{*}$ \\
\hline 79 Transport Equipment & $10.64 \%$ & $-2.58(0.43)$ & $-1.95(2.43)^{* *}$ & $2.16(2.53)^{* *}$ & $-0.34(0.86)$ \\
\hline 81 Prefab Buildings; Sanitary, Plumbing, etc. & $0.11 \%$ & $-1.56(0.53)$ & $1.33(4.34)^{* *}$ & $-0.96(2.06)^{* *}$ & $0.72(3.35)^{* * *}$ \\
\hline 82 Furniture \& Bedding & $0.77 \%$ & $15.19(2.73)^{* *}$ & $2.09(3.74)^{* *}$ & $-5.16(5.54)^{* *}$ & $0.14(0.33)$ \\
\hline 83 Travel Goods, Handbags & $0.04 \%$ & $-4.34(0.42)$ & $0.22(0.19)$ & $0.56(0.35)$ & $-0.25(0.33)$ \\
\hline 84 Articles of Apparel and Clothing & $0.39 \%$ & $-39.01(3.91)^{* *}$ & $-3.24(2.85) * *$ & $11.60(7.75)^{* *}$ & $0.01(0.01)$ \\
\hline 85 Footwear & $0.04 \%$ & $71.63(0.65)$ & $-11.47(1.17)$ & $-4.17(0.24)$ & $-2.98(0.47)$ \\
\hline 87 Professional Scientific Instruments & $3.56 \%$ & $-2.08(1.26)$ & $1.23(6.91)^{* *}$ & $-0.74(2.76)^{* *}$ & $0.34(2.94)^{* *}$ \\
\hline 88 Photo Appt, Equipment \& Optical Goods & $0.65 \%$ & $35.67(9.99)^{* *}$ & $-0.80(2.14)^{* *}$ & $-6.87(12.65)^{* *}$ & $0.61(2.53)^{* *}$ \\
\hline 89 Miscellaneous Manufactured Articles & $8.21 \%$ & $-4.73(1.89)^{* *}$ & $-0.94(3.73) * *$ & $1.86(4.60)^{* *}$ & $-0.11(0.53)$ \\
\hline 93 Special Transactions & $5.25 \%$ & $-2.25(0.29)$ & $-1.63(1.43)$ & $2.53(2.21)^{* *}$ & $0.24(0.44)$ \\
\hline 95 Coin Including Gold & $0.01 \%$ & $-0.44(0.03)$ & $-4.55(2.73)^{* *}$ & $4.99(2.40)^{* *}$ & $-2.28(2.33) * *$ \\
\hline 96 Coin (Other Than Gold) & $0.01 \%$ & $-119.59(1.88)^{*}$ & $3.15(0.46)$ & $23.95(2.77)^{* *}$ & $12.62(4.00) * *$ \\
\hline 97 Gold, Nonmonetary & $4.56 \%$ & $44.61(1.16)$ & $6.20(1.35)$ & $-17.53(2.66)^{* *}$ & $-5.41(1.81)^{*}$ \\
\hline
\end{tabular}




\begin{tabular}{|c|c|c|c|c|c|}
\hline 98 Estimate of Low Valued Import Transactions & $0.40 \%$ & $-23.45(2.52)^{* *}$ & $2.65(2.87)^{* * *}$ & $6.11(4.15)^{* *}$ & $-1.08(1.73)^{*}$ \\
\hline 99 Low Value Shipments & $1.24 \%$ & $-14.49(1.13)$ & $-2.12(1.51)$ & $1.33(0.72)$ & $0.84(0.75)$ \\
\hline
\end{tabular}

Notes: Numbers inside parentheses are the absolute values of the t-ratios. The critical value of standard t-ratio is $1.64(1.96)$ at the $10 \%(5 \%)$ significance level. * indicates significance at the $10 \%$ level and $* *$ at the 5\% level. Trade share is based on sum of imports and exports in the year 2018 . 
Table 3: Diagnostic Statistics Associated with Linear ARDL Model (2)

\begin{tabular}{|c|c|c|c|c|c|c|c|}
\hline \multirow{2}{*}{ Industries } & \multicolumn{7}{|c|}{ Diagnostics } \\
\hline & $F$ & $E C M_{t-1}$ & $L M$ & RESET & CUSUM & CUSUMSQ & $\operatorname{Adj.} R^{2}$ \\
\hline TB (US- UK Trade Balance Aggregate) & $3.487 *$ & $-0.25(4.20)^{* *}$ & 4.76 & 1.450 & $\mathrm{~S}$ & $\mathrm{~S}$ & 0.464 \\
\hline 00 Live Animals & $55.93 * * *$ & $-1.03(16.37)^{* * *}$ & 3.05 & 0.588 & $\mathrm{~S}$ & $\mathrm{~S}$ & 0.064 \\
\hline 01 Meat And Meant Preparations & $5.94 * *$ & $-0.36(5.50)^{* *}$ & 3.21 & 0.001 & $\mathrm{~S}$ & $\mathrm{~S}$ & 0.610 \\
\hline 02 Dairy Products and Birds Eggs & $9.75 * *$ & $-0.51(7.04)^{* *}$ & 6.45 & 2.58 & $\mathrm{~S}$ & $\mathrm{~S}$ & 0.409 \\
\hline 03 Fish (Except Marine Mammal ) & $10.24 * * *$ & $-0.32(7.21)^{* *}$ & 3.79 & 1.21 & $\mathrm{~S}$ & $S$ & 0.685 \\
\hline 04 Cereals And Cereal Preparation & $30.18^{* * *}$ & $-0.73(12.37)^{* *}$ & 2.85 & 0.93 & $\mathrm{~S}$ & $S$ & 0.314 \\
\hline 05 Vegetables and Fruits & $11.13^{* *}$ & $-0.48(7.51)^{* *}$ & 4.22 & 0.71 & $\mathrm{~S}$ & $\mathrm{~S}$ & 0.439 \\
\hline 06 Sugars, Sugar Preparations & $3.34 *$ & $-0.19(4.12)^{* *}$ & 4.85 & 1.39 & $\mathrm{~S}$ & $\mathrm{~S}$ & 0.799 \\
\hline 07 Coffee, Tea, Cocoa & $11.97 * *$ & $-0.51(7.79)^{* *}$ & 2.87 & 0.06 & $\mathrm{~S}$ & $S$ & 0.683 \\
\hline 08 Feeding Stuff For Animals & 2.63 & $-0.18(3.65)^{* *}$ & 5.00 & 1.29 & $\mathrm{~S}$ & $\mathrm{~S}$ & 0.581 \\
\hline 09 Miscellaneous Edible & $13.72 * *$ & $-0.55(8.34)^{* *}$ & 3.38 & 0.37 & $\mathrm{~S}$ & $S$ & 0.516 \\
\hline 11 Beverages & $10.21 * *$ & $-0.69(7.21)^{* *}$ & 1.63 & 1.31 & $\mathrm{~S}$ & $S$ & 0.275 \\
\hline 12 Tobacco and Tobacco & $11.33^{* *}$ & $-0.60(7.59)^{* *}$ & 4.90 & 0.36 & $\mathrm{~S}$ & $\mathrm{~S}$ & 0.346 \\
\hline 21 Hides, Skins and Fur-skins & $21.61 * *$ & $-0.71(10.50)^{* *}$ & 3.61 & 0.03 & $\mathrm{~S}$ & $S$ & 0.145 \\
\hline 22 Oil Seeds and Oleaginous & $8.05^{* *}$ & $-0.58(6.47)^{* *}$ & 1.71 & 0.49 & $\mathrm{~S}$ & $S$ & 0.200 \\
\hline 23 Crude Rubber & 2.57 & $-0.21(3.61)^{* *}$ & 1.83 & 1.62 & $\mathrm{~S}$ & $\mathrm{~S}$ & 0.497 \\
\hline 24 Cork and Wood & $4.24 *$ & $-0.324(4.64)^{* *}$ & 5.12 & 0.34 & $\mathrm{~S}$ & $S$ & 0.712 \\
\hline 25 Pulp and Waste Paper & 2.09 & $-0.022(3.34)^{* *}$ & 10.26 & 3.46 & $S$ & $S$ & 0.379 \\
\hline 26 Textile Fibers & $3.380 *$ & $-0.23(4.14)^{* *}$ & 3.28 & 0.220 & $\mathrm{~S}$ & $\mathrm{~S}$ & 0.575 \\
\hline 27 Crude Fertilizers & $5.30 * *$ & $-0.40(5.19)^{* *}$ & 1.48 & 0.666 & $\mathrm{~S}$ & $\mathrm{~S}$ & 0.254 \\
\hline 28 Metalliferous Ores & $5.93 * *$ & $-0.33(5.48)^{* *}$ & 4.15 & 0.779 & $\mathrm{~S}$ & $S$ & 0.456 \\
\hline 29 Crude Animal and Vegetable Materials & $25.837 * *$ & $-0.66(11.45)^{* *}$ & 0.44 & 1.42 & $\mathrm{~S}$ & $\mathrm{~S}$ & 0.255 \\
\hline 32 Coal, Coke and Briquettes & $5.657 * *$ & $-0.63(5.50)^{* *}$ & 1.97 & 0.814 & $\mathrm{~S}$ & $S$ & 0.167 \\
\hline 33 Petroleum, Petroleum Products & $5.321 * *$ & $-0.36(5.20)^{* *}$ & 4.29 & 2.51 & $\mathrm{~S}$ & $\mathrm{~S}$ & 0.627 \\
\hline 34 Gas, Natural and Manufactured & 2.969 & $-0.90(4.34)^{* *}$ & 0.11 & 1.87 & $\mathrm{~S}$ & $\mathrm{~S}$ & 0.116 \\
\hline 41 Animal Oils and Fats & 1.95 & $-0.23(3.14)^{* *}$ & 4.07 & 0.07 & $\mathrm{~S}$ & $\mathrm{~S}$ & 0.484 \\
\hline 42 Fixed Veg. Fats \& Oils & $8.14 * *$ & $-0.53(6.43)^{* *}$ & 0.80 & 0.84 & $\mathrm{~S}$ & $S$ & 0.136 \\
\hline 43 Animal/Veg Fats/Oils Process/Waste & 1.41 & $-0.16(2.68)^{* *}$ & 3.39 & 0.238 & $\mathrm{~S}$ & $\mathrm{~S}$ & 0.440 \\
\hline 51 Organic Chemicals & $4.03 * *$ & $-0.37(4.50)^{* *}$ & 1.98 & 0.915 & $\mathrm{~S}$ & $\mathrm{~S}$ & 0.221 \\
\hline 52 Inorganic Chemicals & $3.848^{* *}$ & $-0.47(4.42)^{* *}$ & 1.16 & 0.293 & $\mathrm{~S}$ & $\mathrm{~S}$ & 0.147 \\
\hline 53 Dyeing, Tanning and Coloring Materials & $6.862 * *$ & $-0.43(5.90)^{* *}$ & 1.17 & 1.392 & $\mathrm{~S}$ & $\mathrm{~S}$ & 0.264 \\
\hline 54 Medicinal and Pharmaceutical Products & $4.747 * *$ & $-0.33(4.91)^{* *}$ & 1.22 & 0.037 & $\mathrm{~S}$ & $\mathrm{~S}$ & 0.437 \\
\hline
\end{tabular}




\begin{tabular}{|c|c|c|c|c|c|c|c|}
\hline 55 Essential Oils & 2.331 & $-0.22(3.44)^{* *}$ & 0.870 & 0.984 & $\mathrm{~S}$ & $\mathrm{~S}$ & 0.430 \\
\hline 56 Fertilizers & $32.874 * *$ & $-0.77(12.92)^{* *}$ & 1.357 & 1.811 & $\mathrm{~S}$ & $\mathrm{~S}$ & 0.095 \\
\hline 57 Plastics in Primary Form & $8.317 * *$ & $-0.55(6.50)^{* *}$ & 2.010 & 0.515 & $\mathrm{~S}$ & $\mathrm{~S}$ & 0.164 \\
\hline 58 Plastics in Non-primary Form & $4.674 * *$ & $-0.38(4.71)^{* *}$ & 0.279 & 1.238 & $\mathrm{~S}$ & $\mathrm{~S}$ & 0.238 \\
\hline 59 Chemical Materials & $5.863 * *$ & $-0.40(5.46) * *$ & 0.409 & 0.586 & $\mathrm{~S}$ & $\mathrm{~S}$ & 0.401 \\
\hline 61 Leather, Leather MFR & $4.852 * *$ & $-0.33(4.96)^{* *}$ & 0.089 & 0.749 & $\mathrm{~S}$ & $\mathrm{~S}$ & 0.321 \\
\hline 62 Rubber Manufactures & 1.767 & $-0.11(3.00)^{* *}$ & 4.262 & 0.150 & $\mathrm{~S}$ & $\mathrm{~S}$ & 0.675 \\
\hline 63 Cork and Wood Manufactures & $6.602 * *$ & $-0.45(5.79)^{* *}$ & 0.356 & 1.511 & $\mathrm{~S}$ & $\mathrm{~S}$ & 0.547 \\
\hline 64 Paper, Paperboard & $9.715^{* *}$ & $-0.43(7.02)^{* *}$ & 1.387 & 1.734 & $\mathrm{~S}$ & $\mathrm{~S}$ & 0.632 \\
\hline 65 Textile Yarn, Fabrics & 2.106 & $-0.24(3.27)^{* *}$ & 2.041 & 0.621 & $\mathrm{~S}$ & $\mathrm{~S}$ & 0.550 \\
\hline 66 Nonmetallic Mineral & 1.316 & $-0.16(2.57)^{* *}$ & 3.122 & 3.416 & $\mathrm{~S}$ & $\mathrm{~S}$ & 0.776 \\
\hline 67 Iron and Steel & $5.298 * *$ & $-0.35(5.19)^{* *}$ & 1.831 & 1.485 & $\mathrm{~S}$ & $\mathrm{~S}$ & 0.387 \\
\hline 68 Nonferrous Metals & $4.947 * *$ & $-0.39(5.01)^{* *}$ & 0.165 & 0.055 & $\mathrm{~S}$ & $\mathrm{~S}$ & 0.319 \\
\hline 69 Manufactures of Metals & $9.243 * *$ & $-0.58(6.85)^{* *}$ & 1.487 & 1.010 & $\mathrm{~S}$ & $\mathrm{~S}$ & 0.372 \\
\hline 71 Power Generating Machinery & $4.012 * *$ & $-0.26(4.51)^{* *}$ & 2.534 & 1.516 & $\mathrm{~S}$ & $\mathrm{~S}$ & 0.692 \\
\hline 72 Machinery Specialised & 2.567 & $-0.22(3.61)^{* *}$ & 0.276 & 0.326 & $\mathrm{~S}$ & $\mathrm{~S}$ & 0.597 \\
\hline 73 Metalworking Machinery & $4.826 * *$ & $-0.35(4.95)^{* *}$ & 0.784 & 1.866 & $\mathrm{~S}$ & $\mathrm{~S}$ & 0.340 \\
\hline 74 General Industrial Machinery & 1.432 & $-0.20(2.70)^{* *}$ & 0.615 & 0.726 & $\mathrm{~S}$ & $\mathrm{~S}$ & 0.471 \\
\hline 75 Office Machines and ADP Equipment & $3.774 *$ & $-0.31(4.36)^{* *}$ & 3.123 & 2.199 & $\mathrm{~S}$ & $\mathrm{~S}$ & 0.607 \\
\hline 76 Telecommunications Equipment & $6.223 * *$ & $-0.40(5.62)^{* *}$ & 0.078 & 1.087 & $\mathrm{~S}$ & $\mathrm{~S}$ & 0.385 \\
\hline 77 Electrical Machinery, Apparatus \& Appliances & $4.317 * *$ & $-0.34(4.68)^{* *}$ & 1.842 & 2.083 & $\mathrm{~S}$ & $\mathrm{~S}$ & 0.738 \\
\hline 78 Motor Vehicles & $4.178 * *$ & $-0.38(4.61)^{* *}$ & 1.551 & 0.763 & $\mathrm{~S}$ & $\mathrm{~S}$ & 0.367 \\
\hline 79 Transport Equipment & $9.608 * *$ & $-0.58(6.98)^{* *}$ & 1.362 & 1.345 & $\mathrm{~S}$ & $\mathrm{~S}$ & 0.298 \\
\hline 81 Prefab Buildings; Sanitary, Plumbing, etc. & $39.328 * *$ & $-0.86(14.13)^{* *}$ & 0.964 & 1.429 & $\mathrm{~S}$ & $\mathrm{~S}$ & 0.226 \\
\hline 82 Furniture \& Bedding & $3.951^{*}$ & $-0.30(4.48)^{* *}$ & 0.385 & 0.546 & $\mathrm{~S}$ & $\mathrm{~S}$ & 0.777 \\
\hline 83 Travel Goods, Handbags & $3.227^{*}$ & $-0.32(4.05)^{* *}$ & 1.204 & 0.063 & $\mathrm{~S}$ & $\mathrm{~S}$ & 0.287 \\
\hline 84 Articles of Apparel and Clothing & $3.794 *$ & $-0.20(4.39)^{* *}$ & 0.348 & 2.759 & $\mathrm{~S}$ & $\mathrm{~S}$ & 0.921 \\
\hline 85 Footwear & 0.680 & $-0.047(1.86)^{*}$ & 0.166 & 2.544 & $\mathrm{~S}$ & $S$ & 0.867 \\
\hline 87 Professional Scientific Instruments & $8.406 * *$ & $-0.56(6.53) * *$ & 0.789 & 0.722 & $\mathrm{~S}$ & $\mathrm{~S}$ & 0.605 \\
\hline 88 Photo Appt, Equipment \& Optical Goods & $14.550 *$ & $-0.54(8.60)^{* *}$ & 3.555 & 1.080 & $\mathrm{~S}$ & $\mathrm{~S}$ & 0.753 \\
\hline 89 Miscellaneous Manufactured Articles & $13.300 * *$ & $-0.98(8.22)^{* *}$ & 2.839 & 1.599 & $\mathrm{~S}$ & $\mathrm{~S}$ & 0.229 \\
\hline 93 Special Transactions & 2.824 & $-0.37(3.79)^{* *}$ & 0.541 & 0.711 & $\mathrm{~S}$ & $\mathrm{~S}$ & 0.334 \\
\hline 95 Coin Including Gold & $40.901 * *$ & $-0.94(14.42)^{* *}$ & 0.654 & 0.102 & $\mathrm{~S}$ & $\mathrm{~S}$ & 0.141 \\
\hline 96 Coin (Other Than Gold) & $6.064 * *$ & $-0.56(5.59)^{* *}$ & 0.462 & 0.757 & $\mathrm{~S}$ & $\mathrm{~S}$ & 0.350 \\
\hline 97 Gold, Nonmonetary & $7.383 * *$ & $-0.54(6.13)^{* *}$ & 1.348 & 3.738 & $\mathrm{~S}$ & $\mathrm{~S}$ & 0.228 \\
\hline
\end{tabular}




\begin{tabular}{|c|c|c|c|c|c|c|c|}
\hline 98 Estimate of Low Valued Import Transactions & $4.370 * *$ & $-0.11(4.71)^{* *}$ & 0.781 & 0.429 & $\mathrm{~S}$ & $\mathrm{~S}$ & 0.900 \\
\hline 99 Low Value Shipments & 1.302 & $-0.07(2.57) *$ & 0.720 & 1.129 & $S$ & $S$ & 0.798 \\
\hline
\end{tabular}

Notes:

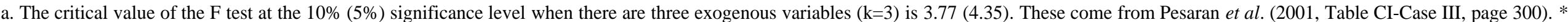

**) indicates a significant statistic at the $10 \%(5 \%)$ level.

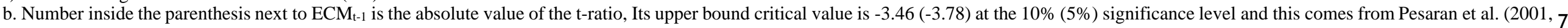
Table CII-Case III, page 303).

c. LM is the Lagrange Multiplier test of residual serial correlation. It is distributed as $\chi^{2}$ with 12 degrees of freedom. Its critical value at the $10 \%$ (5\%) level is 18.55 (21.03).

$\mathrm{d}$. RESET is Ramsey's test for misspecification. It is distributed as $\chi^{2}$ with one degree of freedom and its critical value at $10 \%$ (5\%) level is 2.71 (3.84).

e. Abbreviation n.e.s. stands for not elsewhere specified. 
Table 4: Short-Run Coefficient Estimates of USD Appreciation in the Nonlinear ARDL Model (3)

\begin{tabular}{|c|c|c|c|c|c|c|c|c|c|}
\hline Code & $\triangle P O S_{t}$ & $\triangle P O S_{t-1}$ & $\Delta P O S_{t-2}$ & $\Delta P O S_{t-3}$ & $\triangle P^{\prime} O S_{t-4}$ & $\Delta P_{O S S_{t-5}}$ & $\triangle P_{O S S_{t-6}}$ & $\Delta \boldsymbol{P O S}_{t-7}$ & $\Delta$ POS $_{t-8}$ \\
\hline TB & $-0.02(0.25)$ & & & & & & & & \\
\hline 00 & $2.02(1.90) * *$ & & & & & & & & \\
\hline 01 & $-7.99(2.30)$ & $3.59(1.02)$ & $3.36(0.93)$ & $3.45(0.96)$ & $-4.46(-1.26)$ & $10.13(3.12)$ & & & \\
\hline 02 & $-2.28(0.72)$ & $3.73(1.20)$ & $-0.10(0.03)$ & $-8.27(2.63)^{* *}$ & $-5.77(1.80)^{*}$ & & & & \\
\hline 03 & $0.32(1.15)$ & & & & & & & & \\
\hline 04 & $0.61(1.64)^{*}$ & & & & & & & & \\
\hline 05 & $0.56(2.10)^{* *}$ & & & & & & & & \\
\hline 06 & $-4.21(1.13)$ & & & & & & & & \\
\hline 07 & $1.14(0.46)$ & $5.49(2.18) * *$ & $-3.51(1.40)$ & $0.37(0.14)$ & $5.73(2.27)^{* *}$ & & & & \\
\hline 08 & $-0.60(0.72)$ & & & & & & & & \\
\hline 09 & $-3.22(2.33)^{* *}$ & & & & & & & & \\
\hline 11 & $0.39(1.93)^{*}$ & & & & & & & & \\
\hline 12 & $-1.35(1.25)$ & & & & & & & & \\
\hline 21 & $-2.65(2.03)^{* *}$ & & & & & & & & \\
\hline 22 & $7.92(0.43)$ & $43.50(2.31)^{* *}$ & $60.05(2.48)^{* *}$ & $16.38(1.05)$ & $17.33(0.95)$ & & & & \\
\hline 23 & $-0.51(1.46)$ & & & & & & & & \\
\hline 24 & $0.06(0.09)$ & & & & & & & & \\
\hline 25 & $13.55(1.49)$ & $-31.20(3.04)^{* *}$ & & & & & & & \\
\hline 26 & $0.33(0.94)$ & & & & & & & & \\
\hline 27 & $1.84(0.98)$ & $2.88(1.51)$ & & & & & & & \\
\hline 28 & $-4.25(1.32)$ & & & & & & & & \\
\hline 29 & $-0.23(0.67)$ & & & & & & & & \\
\hline 32 & $-496.50(4.1)^{* *}$ & $-423.61(3.00) * *$ & $-276.05(3.1)^{* *}$ & & & & & & \\
\hline 33 & $9.89(2.12)^{* *}$ & & & & & & & & \\
\hline 34 & $-4.09(0.09)$ & $-38.31(0.71)$ & $44.23(0.81)$ & & & & & & \\
\hline 41 & $-7.22(0.94)$ & $4.38(0.56)$ & $-13.16(1.67)^{*}$ & $11.95(1.54)$ & $-19.93(2.57)^{* *}$ & & & & \\
\hline 42 & $-2.83(0.54)$ & $9.84(1.91)^{*}$ & $3.40(0.69)$ & $-6.37(1.29)$ & $10.97(2.20)^{* *}$ & & & & \\
\hline 43 & $-1.53(1.15)$ & & & & & & & & \\
\hline 51 & $-1.72(0.63)$ & $7.6917(2.78)^{* *}$ & & & & & & & \\
\hline 52 & $-0.86(1.31)$ & & & & & & & & \\
\hline 53 & $-0.14(0.90)$ & & & & & & & & \\
\hline 54 & $2.18(1.46)$ & & & & & & & & \\
\hline 55 & $0.33(2.55) * *$ & & & & & & & & \\
\hline
\end{tabular}




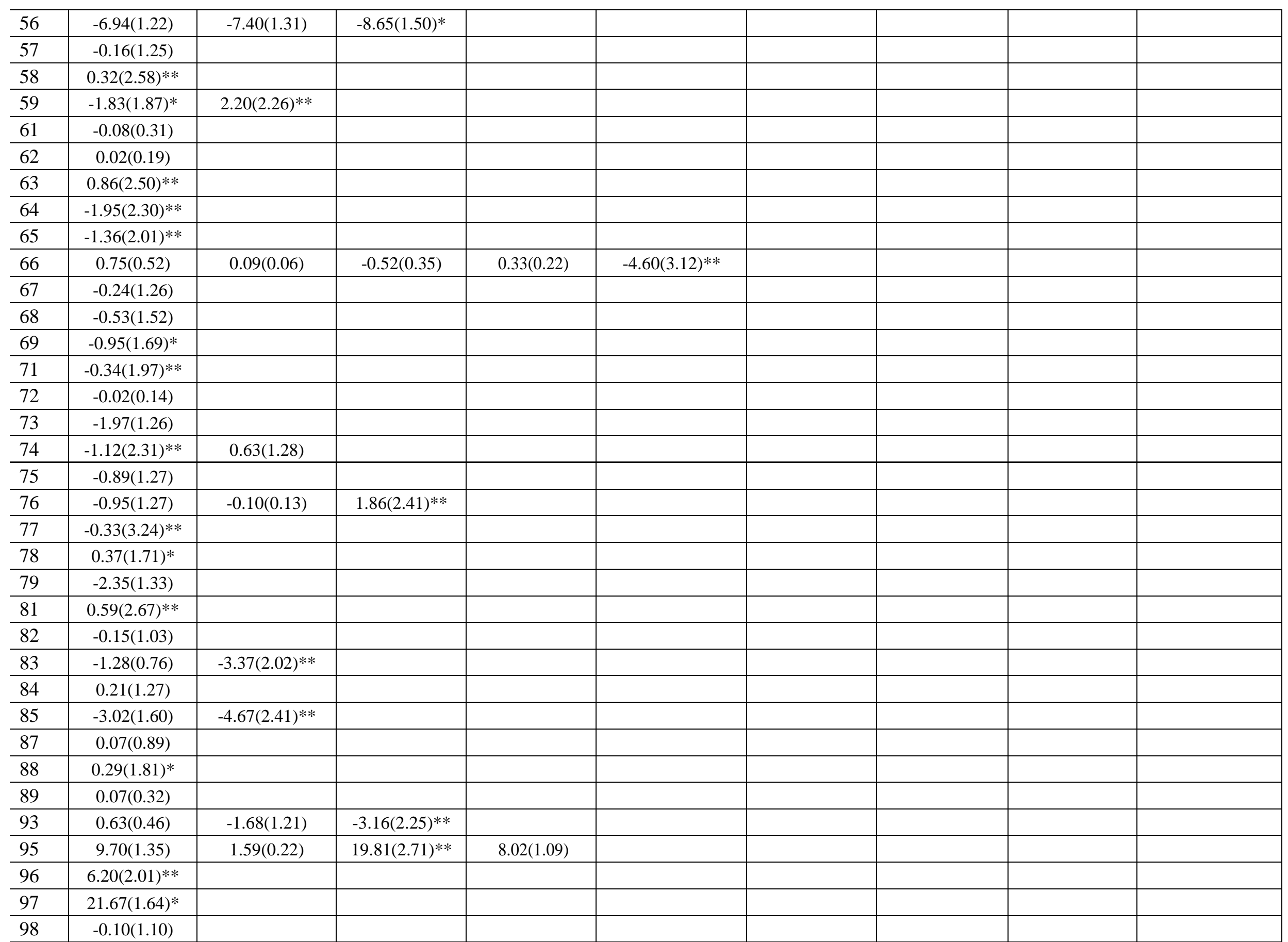




\begin{tabular}{l|l|l|l|l|l|l|l|l|}
\hline 99 & $0.08(1.167)$ & & & & & & & \\
\hline
\end{tabular}

Notes: Numbers inside parentheses are the absolute values of the t-ratios.The critical value of standard t-ratio is $1.64(1.96)$ at the $10 \%$ (5\%) significance level. * indicates significance at the $10 \%$ leveland $* *$ at the $5 \%$ level. 
Table 5: Short-Run Coefficient Estimates of USD Depreciation in the Nonlinear ARDL Model (3)

\begin{tabular}{|c|c|c|c|c|c|c|c|c|c|}
\hline Ind. & $\Delta N E G_{t}$ & $\Delta \boldsymbol{N E} \boldsymbol{G}_{\mathrm{t}-1}$ & $\Delta N E G_{t-2}$ & $\Delta N E G_{t-3}$ & $\Delta N E G_{t-4}$ & $\Delta \boldsymbol{N E G _ { t - 5 }}$ & $\Delta N E G_{t-6}$ & $\Delta \boldsymbol{N E G _ { t - 7 }}$ & $\Delta \boldsymbol{N E G _ { t - 8 }}$ \\
\hline TB & $-1.19(2.04)$ & & & & & & & & \\
\hline 00 & $16.54(2.23)^{* *}$ & & & & & & & & \\
\hline 01 & $3.15(0.79)$ & $-0.39(0.10)$ & $-1.35(-0.34)$ & $1.77(0.45)$ & $14.02(3.62)^{* *}$ & & & & \\
\hline 02 & $2.25(0.63)$ & $2.46(0.68)$ & $-2.01(-0.56)$ & $7.72(2.19) * *$ & $5.03(1.44)$ & $6.83(2.08)^{* *}$ & & & \\
\hline 03 & $0.003(0.009)$ & & & & & & & & \\
\hline 04 & $0.49(0.99)$ & & & & & & & & \\
\hline 05 & $0.71(2.10)^{* *}$ & & & & & & & & \\
\hline 06 & $-2.43(0.66)$ & $7.15(2.07)^{* *}$ & & & & & & & \\
\hline 07 & $-0.52(098)$ & & & & & & & & \\
\hline 08 & $-0.88(0.78)$ & & & & & & & & \\
\hline 09 & $-0.68(2.21)^{* *}$ & & & & & & & & \\
\hline 11 & $0.57(2.10)^{* *}$ & & & & & & & & \\
\hline 12 & $-1.22(0.84)$ & & & & & & & & \\
\hline 21 & $-5.11(2.85)^{* *}$ & & & & & & & & \\
\hline 22 & $-11.46(0.28)$ & $-99.64(2.91)^{* *}$ & $-131.83(3.66)^{* *}$ & $-71.29(1.81)^{*}$ & $-95.95(2.91)^{* *}$ & $-101.41(3.10)^{* *}$ & & & \\
\hline 23 & $3.98(1.63)$ & & & & & & & & \\
\hline 24 & $0.10(0.11)$ & & & & & & & & \\
\hline 25 & $5.27(1.71)^{*}$ & & & & & & & & \\
\hline 26 & $0.63(1.29)$ & & & & & & & & \\
\hline 27 & $0.11(0.28)$ & & & & & & & & \\
\hline 28 & $8.848(2.51)^{* *}$ & & & & & & & & \\
\hline 29 & $-3.58(1.53)$ & $3.50(1.46)$ & & & & & & & \\
\hline 32 & $225.89(3.47)^{* *}$ & $61.64(1.02)$ & $-75.54(1.37)$ & & & & & & \\
\hline 33 & $-11.22(2.08) * *$ & & & & & & & & \\
\hline 34 & $2.06(0.22)$ & & & & & & & & \\
\hline 41 & $0.53(0.31)$ & & & & & & & & \\
\hline 42 & $-6.31(1.08)$ & $-10.26(1.173)^{*}$ & & & & & & & \\
\hline 43 & $-2.61(1.57)$ & & & & & & & & \\
\hline 51 & $3.84(1.24)$ & $-4.68(1.51)$ & & & & & & & \\
\hline 52 & $-0.64(0.76)$ & & & & & & & & \\
\hline 53 & $-0.24(1.168)$ & & & & & & & & \\
\hline 54 & $-6.48(3.84)^{* *}$ & & & & & & & & \\
\hline 55 & $0.48(2.60)^{* *}$ & & & & & & & & \\
\hline
\end{tabular}




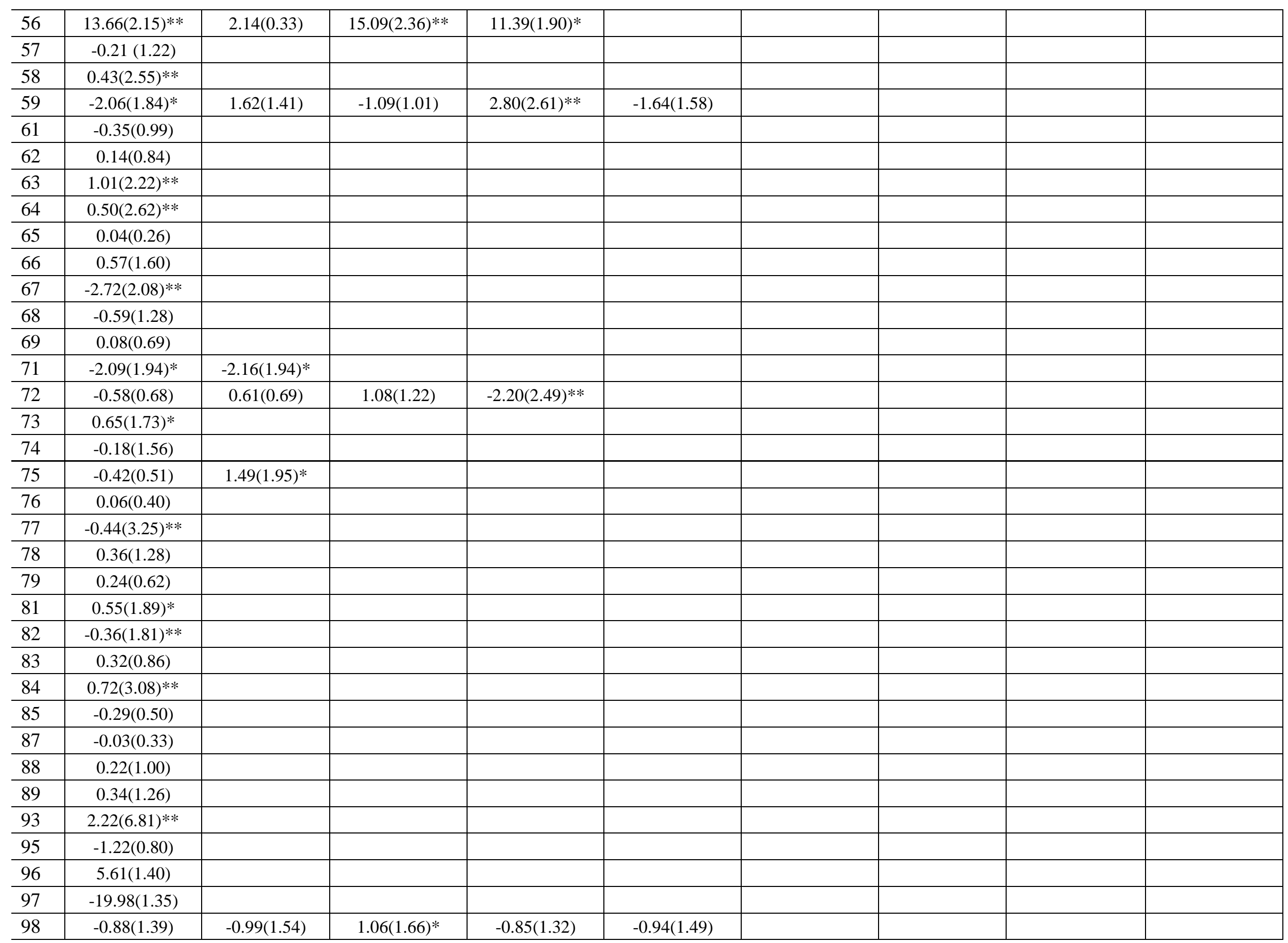




\begin{tabular}{l|l|l|l|l|l|}
\hline 99 & $0.15(1.69)^{*}$ & & & & \\
\hline
\end{tabular}
Notes: Numbers inside parentheses are the absolute value of the t-ratios. The critical value of standard t-ratio is $1.64(1.96)$ at the $10 \%(5 \%)$ significance level. *indicates significance
at the $10 \%$ leveland ** at the 5\% level.
at the $10 \%$ leveland $* *$ at the $5 \%$ level. 
Table 6: Long-Run Coefficient Estimates of Nonlinear ARDL Model (3)

\begin{tabular}{|c|c|c|c|c|c|c|}
\hline Industries & Trade Share & Constant & $\operatorname{Ln} Y_{U S}$ & $\operatorname{Ln} Y_{U K}$ & POS & $N E G$ \\
\hline TB (US- UK Trade Balance Aggregate) & $100 \%$ & $-2.17(0.53)$ & $2.10(2.04)^{* *}$ & $-1.54(1.16)$ & $-0.07(0.26)$ & $0.25(0.60)$ \\
\hline 00 Live Animals & $0.18 \%$ & $-18.19(1.57)$ & $0.93(0.30)$ & $3.06(0.78)$ & $1.92(1.94)^{* *}$ & $2.39(1.75)^{*}$ \\
\hline 01 Meat And Mean Preparations & $0.05 \%$ & $28.63(1.22)$ & $-8.79(1.18)$ & $2.10(0.28)$ & $-0.12(0.03)$ & $-2.27(0.47)$ \\
\hline 02 Dairy Products and Birds Eggs & $0.08 \%$ & $10.76(1.24)$ & $-7.31(3.31)^{* *}$ & $4.94(1.78)^{*}$ & $1.21(1.80)^{*}$ & $-0.12(0.13)$ \\
\hline 03 Fish (Except Marine Mammal ) & $0.22 \%$ & $-6.12(0.62)$ & $-0.71(0.31)$ & $1.80(0.55)$ & $0.92(1.15)$ & $0.009(0.009)$ \\
\hline 04 Cereals And Cereal Preparation & $0.18 \%$ & $0.74(0.115)$ & $1.57(1.14)$ & $-1.80(0.94)$ & $0.85(1.63)$ & $0.67(0.98)$ \\
\hline 05 Vegetables and Fruits & $0.35 \%$ & $7.62(1.10)$ & $3.00(1.65)^{*}$ & $-5.25(2.17)^{* *}$ & $1.16(2.25)^{* *}$ & $1.46(1.95)^{* *}$ \\
\hline 06 Sugars, Sugar Preparations & $0.03 \%$ & $6.84(0.28)$ & $-3.79(0.57)$ & $2.79(0.35)$ & $2.58(1.27)$ & $4.00(1.44)$ \\
\hline 07 Coffee, Tea, Cocoa & $0.09 \%$ & $-4.65(0.63)$ & $-0.74(0.39)$ & $2.11(0.83)$ & $-1.71(2.37)^{* *}$ & $-0.84(0.87)$ \\
\hline 08 Feeding Stuff For Animals & $0.14 \%$ & $-101.26(1.94)^{*}$ & $4.77(0.38)$ & $16.31(0.96)$ & $-3.17(0.73)$ & $-4.63(0.81)$ \\
\hline 09 Miscellaneous Edible & $0.29 \%$ & $34.12(7.30)^{* *}$ & $-3.42(2.88)^{* *}$ & $-4.14(2.56)^{* *}$ & $-0.91(2.70)^{* *}$ & $-1.21(2.36)^{* *}$ \\
\hline 11 Beverages & $2.14 \%$ & $10.91(3.35)^{* *}$ & $0.64(0.88)$ & $-2.64(2.49) * *$ & $0.53(2.10)^{* *}$ & $0.77(2.36)^{* *}$ \\
\hline 12 Tobacco and Tobacco & $0.004 \%$ & $-48.46(1.78)^{*}$ & $9.55(1.64)^{*}$ & $1.08(01.2)$ & $-2.42(1.23)$ & $-2.17(0.84)$ \\
\hline 21 Hides, Skins and Fur-skins & $0.002 \%$ & $-105.14(4.53)^{* *}$ & $-12.66(2.00)^{* *}$ & $34.07(4.26) * *$ & $-3.48(2.13) * *$ & $-6.71(2.81)^{* *}$ \\
\hline 22 Oil Seeds and Oleaginous & $0.10 \%$ & $-50.82(1.87)^{*}$ & $23.08(2.13)^{* *}$ & $-12.89(0.99)$ & $-2.18(0.81)$ & $-0.29(0.07)$ \\
\hline 23 Crude Rubber & $0.07 \%$ & $13.89(0.74)$ & $-6.96(1.34)$ & $3.56(0.56)$ & $-2.12(1.40)$ & $-3.17(1.50)$ \\
\hline 24 Cork and Wood & $0.57 \%$ & $-83.01(2.11)^{* *}$ & $-7.06(0.81)$ & $23.84(1.60)$ & $0.18(0.09)$ & $0.30(0.11)$ \\
\hline 25 Pulp and Waste Paper & $0.01 \%$ & $-1313.99(0.39)$ & $-76.39(0.44)$ & $351.72(0.41)$ & $80.36(0.39)$ & $50.63(0.40)$ \\
\hline 26 Textile Fibers & $0.03 \%$ & $-38.86(2.36)^{* *}$ & $6.42(1.91)^{*}$ & $2.22(0.40)$ & $1.19(0.99)$ & $2.28(1.38)$ \\
\hline 27 Crude Fertilizers & $0.06 \%$ & $-4.66(0.59)$ & $3.51(1.97)^{* *}$ & $-2.58(0.98)$ & $-0.42(0.69)$ & $0.22(0.27)$ \\
\hline 28 Metalliferous Ores & $1.07 \%$ & $-3.37(0.20)$ & $1.34(0.31)$ & $-0.70(0.13)$ & $3.21(2.20) * *$ & $3.79(1.92) *$ \\
\hline 29 Crude Animal and Vegetable Materials & $0.07 \%$ & $1.54(0.25)$ & $1.75(1.23)$ & $-2.12(1.08)$ & $-0.33(0.69)$ & $0.30(0.47)$ \\
\hline 32 Coal, Coke and Briquettes & $0.29 \%$ & $-1008.46(0.96)$ & $-149.71(0.69)$ & $363.40(0.86)$ & $49.63(0.87)$ & $9.90(0.38)$ \\
\hline 33 Petroleum, Petroleum Products & $7.57 \%$ & $-2.70(0.14)$ & $8.77(2.19)^{* * *}$ & $-6.93(1.10)$ & $-1.98(1.34)$ & $1.04(0.52)$ \\
\hline 34 Gas, Natural and Manufactured & $0.30 \%$ & $-64.59(0.34)$ & $6.63(0.21)$ & $8.04(0.17)$ & $-0.33(0.05)$ & $2.32(0.25)$ \\
\hline 41 Animal Oils and Fats & $0.02 \%$ & $-3.94(0.07)$ & $23.23(1.68)^{*}$ & $-20.83(1.53)$ & $-3.16(0.73)$ & $1.76(0.31)$ \\
\hline 42 Fixed Veg. Fats \& Oils & $0.01 \%$ & $-20.02(1.16)$ & $-0.98(0.21)$ & $5.13(0.96)$ & $-2.16(1.45)$ & $-2.67(1.30)$ \\
\hline 43 Animal/Veg Fats/Oils Process/Waste & $0.02 \%$ & $-72.44(0.59)$ & $-28.66(1.30)$ & $42.33(1.02)$ & $-8.76(1.16)$ & $-14.91(1.61)$ \\
\hline 51 Organic Chemicals & $2.51 \%$ & $-5.15(0.46)$ & $-5.09(1.97)^{* *}$ & $6.20(1.74)^{*}$ & $-2.24(2.64)^{* *}$ & $-3.21(2.82)^{* *}$ \\
\hline 52 Inorganic Chemicals & $0.42 \%$ & $15.27(0.97)$ & $2.99(0.88)$ & $-6.06(1.18)$ & $-1.79(1.49)$ & $-1.32(0.88)$ \\
\hline 53 Dyeing, Tanning and Coloring Materials & $0.24 \%$ & $-8.07(1.95)^{* *}$ & $-1.019(1.167)$ & $2.75(2.10)^{* *}$ & $-0.29(0.88)$ & $-0.50(1.183)$ \\
\hline 54 Medicinal and Pharmaceutical Products & $6.96 \%$ & $-8.22(0.85)$ & $0.78(0.38)$ & $1.10(0.36)$ & $-0.14(0.21)$ & $0.09(0.10)$ \\
\hline 55 Essential Oils & $1.28 \%$ & $-1.57(0.42)$ & $2.46(2.57)^{* *}$ & $-2.09(1.73)^{*}$ & $1.01(3.48)^{* * *}$ & $1.46(3.66)^{* *}$ \\
\hline
\end{tabular}




\begin{tabular}{|c|c|c|c|c|c|c|}
\hline 56 Fertilizers & $0.02 \%$ & $-8.89(0.727)$ & $4.98(1.62)$ & $-2.77(0.63)$ & $1.52(1.66)^{*}$ & $2.11(1.66)^{*}$ \\
\hline 57 Plastics in Primary Form & $0.57 \%$ & $4.18(1.38)$ & $-0.43(0.64)$ & $-0.570(0.57)$ & $-0.29(1.25)$ & $-0.37(1.23)$ \\
\hline 58 Plastics in Non-primary Form & $0.64 \%$ & $1.66(0.60)$ & $1.08(1.46)$ & $-1.44(1.49)$ & $0.73(3.33)^{* *}$ & $0.97(3.19)^{* *}$ \\
\hline 59 Chemical Materials & $1.58 \%$ & $-6.75(2.04)^{* *}$ & $-2.29(2.29)^{* *}$ & $3.58(3.16) * *$ & $-0.99(3.39)^{* *}$ & $-1.69(4.11)^{* *}$ \\
\hline 61 Leather, Leather MFR & $0.04 \%$ & $-14.46(1.86)^{*}$ & $-4.07(2.23) * *$ & $7.26(3.09)^{* *}$ & $-0.22(0.30)$ & $-0.96(1.00)$ \\
\hline 62 Rubber Manufactures & $0.38 \%$ & $1.78(0.15)$ & $3.63(1.62)$ & $-3.69(1.08)$ & $0.15(0.18)$ & $0.92(0.88)$ \\
\hline 63 Cork and Wood Manufactures & $0.09 \%$ & $-43.30(6.36)^{* *}$ & $1.57(1.03)$ & $7.33(3.52)^{* *}$ & $1.60(2.86)^{* *}$ & $1.88(2.62)^{* * *}$ \\
\hline 64 Paper, Paperboard & $0.52 \%$ & $-13.94(3.22)^{* *}$ & $2.05(2.21)^{* *}$ & $1.04(0.72)$ & $0.59(2.17)^{* *}$ & $1.05(2.79)^{* * *}$ \\
\hline 65 Textile Yarn, Fabrics & $0.44 \%$ & $-11.80(2.21)^{* *}$ & $2.18(1.86)^{*}$ & $0.46(0.28)$ & $-0.12(0.28)$ & $0.15(0.28)$ \\
\hline 66 Nonmetallic Mineral & $1.13 \%$ & $2.66(0.21)$ & $-0.70(0.24)$ & $0.31(0.08)$ & $1.41(1.61)$ & $2.24(1.89)^{*}$ \\
\hline 67 Iron and Steel & $0.59 \%$ & $3.44(0.52)$ & $1.85(1.28)$ & $-2.26(1.04)$ & $-0.64(1.40)$ & $-0.26(0.42)$ \\
\hline 68 Nonferrous Metals & $1.40 \%$ & $-27.25(2.37)^{* *}$ & $1.48(0.58)$ & $4.42(1.25)$ & $-1.37(1.76)^{*}$ & $-1.51(1.47)$ \\
\hline 69 Manufactures of Metals & $1.45 \%$ & $-1.26(0.64)$ & $-0.17(0.41)$ & $0.40(0.63)$ & $0.04(0.29)$ & $0.14(0.72)$ \\
\hline 71 Power Generating Machinery & $4.83 \%$ & $4.56(0.63)$ & $0.022(0.01)$ & $-0.96(0.40)$ & $-1.29(2.25)^{* *}$ & $-1.67(2.06)^{* *}$ \\
\hline 72 Machinery Specialised & $2.40 \%$ & $11.21(1.28)$ & $1.27(0.65)$ & $-3.59(1.17)$ & $-0.08(0.15)$ & $0.06(0.08)$ \\
\hline 73 Metalworking Machinery & $0.28 \%$ & $2.26(0.25)$ & $1.27(0.62)$ & $-1.66(0.53)$ & $1.31(2.02)^{* * *}$ & $1.72(2.03)^{* *}$ \\
\hline 74 General Industrial Machinery & $4.58 \%$ & $2.19(0.39)$ & $-1.34(1.03)$ & $0.86(0.47)$ & $-0.73(1.97)^{* *}$ & $-0.93(1.91)^{*}$ \\
\hline 75 Office Machines and ADP Equipment & $1.47 \%$ & $1.24(0.28)$ & $-0.43(0.44)$ & $0.008(0.006)$ & $0.42(1.36)$ & $0.60(1.44)$ \\
\hline 76 Telecommunications Equipment & $1.64 \%$ & $-9.48(2.69)^{* *}$ & $1.74(2.20)^{* *}$ & $0.18(0.16)$ & $0.05(0.17)$ & $0.16(0.42)$ \\
\hline 77 Electrical Machinery, Apparatus \& Appliances & $3.84 \%$ & $3.11(1.21)$ & $-0.14(0.22)$ & $-0.68(0.87)$ & $-0.81(3.38)^{* *}$ & $-1.09(3.43) * *$ \\
\hline 78 Motor Vehicles & $10.79 \%$ & $-12.89(1.78)^{*}$ & $0.71(0.48)$ & $2.31(1.06)$ & $0.96(1.71)^{*}$ & $0.94(1.32)$ \\
\hline 79 Transport Equipment & $10.64 \%$ & $1.43(0.26)$ & $-0.05(0.03)$ & $-0.46(0.28)$ & $0.013(0.03)$ & $0.40(0.60)$ \\
\hline 81 Prefab Buildings; Sanitary, Plumbing, etc. & $0.11 \%$ & $-2.44(0.74)$ & $1.10(1.47)$ & $-0.63(0.60)$ & $0.68(2.94)^{* *}$ & $0.64(2.03)^{* *}$ \\
\hline 82 Furniture \& Bedding & $0.77 \%$ & $9.61(1.90)^{*}$ & $-0.77(0.60)$ & $-1.26(0.72)$ & $-0.40(1.01)$ & $-0.97(1.72)^{* *}$ \\
\hline 83 Travel Goods, Handbags & $0.04 \%$ & $-0.007(0.007)$ & $2.79(1.12)$ & $-2.76(0.86)$ & $0.39(0.52)$ & $0.91(0.92)$ \\
\hline 84 Articles of Apparel and Clothing & $0.39 \%$ & $-25.59(4.82)^{* *}$ & $3.60(2.86)^{* *}$ & $2.22(1.37)$ & $0.56(1.28)$ & $1.92(3.24)^{* *}$ \\
\hline 85 Footwear & $0.04 \%$ & $64.69(0.59)$ & $-23.24(0.52)$ & $9.14(0.23)$ & $-4.01(0.34)$ & $-6.14(0.33)$ \\
\hline 87 Professional Scientific Instruments & $3.56 \%$ & $-3.80(2.22)^{* *}$ & $0.33(0.81)$ & $0.45(0.88)$ & $0.12(0.93)$ & $-0.06(0.32)$ \\
\hline 88 Photo Appt, Equipment \& Optical Goods & $0.65 \%$ & $33.65(9.58)^{* *}$ & $-1.47(1.65)^{*}$ & $-5.86(5.23) * *$ & $0.53(1.94)^{*}$ & $0.39(0.98)$ \\
\hline 89 Miscellaneous Manufactured Articles & $8.21 \%$ & $-2.72(1.06)$ & $0.30(0.58)$ & $0.26(0.30)$ & $0.06(0.33)$ & $0.30(1.36)$ \\
\hline 93 Special Transactions & $5.25 \%$ & $5.37(1.88)^{*}$ & $3.99(7.78)^{* *}$ & $-4.48(5.01)^{* *}$ & $1.18(5.54)^{* *}$ & $2.23(7.82)^{* *}$ \\
\hline 95 Coin Including Gold & $0.01 \%$ & $0.65(0.05)$ & $-0.82(0.22)$ & $1.33(0.32)$ & $-1.94(1.57)$ & $-1.30(0.77)$ \\
\hline 96 Coin (Other Than Gold) & $0.01 \%$ & $-132.84(1.99)^{* *}$ & $-2.11(0.15)$ & $30.49(1.61)$ & $11.13(2.35)^{* *}$ & $10.07(1.48)$ \\
\hline 97 Gold, Nonmonetary & $4.56 \%$ & $137.65(4.58)^{* *}$ & $33.40(3.85)^{* *}$ & $-62.69(6.54) * *$ & $-2.33(0.86)$ & $3.95(1.02)$ \\
\hline 98 Estimate of Low Valued Import Transactions & $0.40 \%$ & $-22.97(2.30)^{* *}$ & $3.65(1.52)$ & $5.12(1.59)$ & $-0.84(1.29)$ & $-0.68(0.74)$ \\
\hline
\end{tabular}




\begin{tabular}{l}
\hline 99 Low Value Shipments \\
$\begin{array}{l}\text { Notes:Numbers inside parentheses are the t-ratios. The critical value of standard t-ratio is } 1.64(1.96) \text { at the } 10 \%(5 \%) \text { significance level. * indicates significance at } \\
\text { the } 10 \% \text { level and } * * \text { at the 5\% level. }\end{array}$
\end{tabular}


Table 7: Diagnostic Statistics Associated with Nonlinear ARDL Model (3)

\begin{tabular}{|c|c|c|c|c|c|c|c|c|}
\hline Industries & $\boldsymbol{F}$ & $E C M_{t-1}$ & $L M$ & RESET & $C S\left(C S^{2}\right)$ & $\operatorname{Adj} . R^{2}$ & Wald-S & Wald-L \\
\hline TB (US- UK Trade Balance Aggregate) & $3.75 * *$ & $-0.280(4.79)^{* * *}$ & 4.765 & 1.450 & $(\mathrm{~S})(\mathrm{S})$ & 0.472 & $4.479 * *$ & $3.994 * *$ \\
\hline 00 Live Animals & $47.93 * *$ & $-1.04(17.12)^{* *}$ & 4.25 & 0.457 & $(\mathrm{~S})(\mathrm{S})$ & 0.075 & $6.548 * *$ & $3.584 * *$ \\
\hline 01 Meat \& Meat Preparations & $3.67 *$ & $-0.26(4.74)^{* *}$ & 3.90 & 2.53 & $(\mathrm{~S})(\mathrm{S})$ & 0.637 & 0.320 & $2.950 * *$ \\
\hline 02 Dairy Products and Birds Eggs & $10.13 * *$ & $-0.67(7.88)^{* *}$ & 2.61 & 2.13 & $(\mathrm{~S})(\mathrm{S})$ & 0.444 & 0.383 & $13.44 * *$ \\
\hline 03 Fish (Except Marine Mammal ) & $9.279 * *$ & $-0.35(7.53)^{* *}$ & 3.03 & 0.731 & $(\mathrm{~S})(\mathrm{S})$ & 0.689 & 0.185 & $23.699 * *$ \\
\hline 05 Vegetables and Fruits & $9.44 * *$ & $-0.48(7.60)^{* *}$ & 3.68 & 0.63 & $(\mathrm{~S})(\mathrm{S})$ & 0.439 & 0.905 & 1.318 \\
\hline 06 Sugars, Sugar Preparations & $3.33 *$ & $-0.23(3.51)^{* *}$ & 3.79 & 1.36 & $(\mathrm{~S})(\mathrm{S})$ & 0.798 & 1.057 & $55.628 * *$ \\
\hline 07 Coffee, Tea, Cocoa & $10.74 * *$ & $-0.62(8.11)^{* *}$ & 0.834 & 0.061 & $(\mathrm{~S})(\mathrm{S})$ & 0.692 & $6.189 * *$ & $25.970 * *$ \\
\hline 08 Feeding Stuff For Animals & 2.24 & $-0.19(3.71)^{* *}$ & 4.84 & 1.24 & $(\mathrm{~S})(\mathrm{S})$ & 0.580 & 0.591 & $14.773 * *$ \\
\hline 09 Miscellaneous Edible & $11.96 * *$ & $-0.56(8.55)^{* *}$ & 3.61 & 0.205 & $(\mathrm{~S})(\mathrm{S})$ & 0.517 & $6.384 * *$ & $5.805^{* *}$ \\
\hline 12 Tobacco and Tobacco & $9.42 * *$ & $-0.55(7.59)^{* *}$ & 5.00 & 0.491 & $(\mathrm{~S})(\mathrm{S})$ & 0.343 & 0.05 & 0.03 \\
\hline 21 Hides, Skins and Fur-skins & $20.33 * *$ & $-0.76(11.19)^{* *}$ & 1.53 & 1.27 & $(\mathrm{~S})(\mathrm{S})$ & 0.181 & 1.681 & $14.86 * *$ \\
\hline 22 Oil Seeds and Oleaginous & $4.51 *$ & $-2.03(6.12)^{* *}$ & 2.87 & 2.28 & $(\mathrm{~S})(\mathrm{S})$ & 0.322 & 0.034 & $21.42^{* *}$ \\
\hline 23 Crude Rubber & $3.13^{*}$ & $-0.24(4.37)^{* *}$ & 3.45 & 1.53 & $(\mathrm{~S})(\mathrm{S})$ & 0.507 & 0.278 & 2.42 \\
\hline 24 Cork and Wood & $3.52 *$ & $-0.33(4.65)^{* *}$ & 5.14 & 0.44 & $(\mathrm{~S})(\mathrm{S})$ & 0.711 & 0.181 & $12.638 * *$ \\
\hline 25 Pulp and Waste Paper & 1.57 & $-0.10(3.20)^{* *}$ & 11.12 & 5.14 & $(\mathrm{~S})(\mathrm{S})$ & 0.390 & 0.478 & $3.04 *$ \\
\hline 26 Textile Fibers & $3.181 *$ & $-0.27(4.41)^{* *}$ & 3.15 & 0.22 & $(\mathrm{~S})(\mathrm{S})$ & 0.577 & 0.103 & $37.78 * *$ \\
\hline 27 Crude Fertilizers & $8.824 * *$ & $-0.51(7.34)^{*}$ & 4.04 & 0.352 & $(\mathrm{~S})(\mathrm{S})$ & 0.265 & 0.571 & $10.297 * *$ \\
\hline 28 Metalliferous Ores & $5.41 * *$ & $-0.34(5.76)^{* *}$ & 4.18 & 0.328 & $(\mathrm{~S})(\mathrm{S})$ & 0.464 & 0.148 & $4.648 * *$ \\
\hline 29 Crude Animal and Vegetable Materials & $22.45^{* *}$ & $-0.68(11.72)^{* *}$ & 1.00 & 1.46 & $(\mathrm{~S})(\mathrm{S})$ & 0.263 & $5.716^{* *}$ & $7.919 * *$ \\
\hline 32 Coal, Coke and Briquettes & $4.876^{* *}$ & $-0.34(7.08) * *$ & 1.49 & 0.639 & $(\mathrm{~S})(\mathrm{S})$ & 0.496 & 0.023 & 0.010 \\
\hline 33 Petroleum, Petroleum Products & $7.284 * *$ & $-0.47(6.68)^{* *}$ & 1.92 & 1.682 & $(\mathrm{~S})(\mathrm{S})$ & 0.646 & 0.032 & $37.478 * *$ \\
\hline 42 Fixed Veg. Fats \& Oils & $7.47 * *$ & $-0.54(6.76)^{* *}$ & 1.08 & 0.792 & $(\mathrm{~S})(\mathrm{S})$ & 0.167 & $11.741 * *$ & $3.851 * *$ \\
\hline 43 Animal/Veg Fats/Oils Process/Waste & 1.438 & $-0.17(2.97)^{* *}$ & 3.70 & 0.826 & $(\mathrm{~S})(\mathrm{S})$ & 0.442 & 0.378 & $9.807 * *$ \\
\hline 51 Organic Chemicals & $5.344 * *$ & $-0.47(5.72)^{* *}$ & 2.40 & 1.120 & $(\mathrm{~S})(\mathrm{S})$ & 0.252 & 0.685 & $6.901 * *$ \\
\hline 52 Inorganic Chemicals & $3.270^{*}$ & $-0.48(4.47)^{* *}$ & 1.21 & 0.233 & $(\mathrm{~S})(\mathrm{S})$ & 0.144 & 0.149 & 1.681 \\
\hline
\end{tabular}




\begin{tabular}{|c|c|c|c|c|c|c|c|c|}
\hline 53 Dyeing, Tanning and Coloring Materials & $8.422 * *$ & $-0.49(7.17)^{* *}$ & 1.38 & 0.886 & $(\mathrm{~S})(\mathrm{S})$ & 0.262 & 1.334 & $8.796 * *$ \\
\hline 54 Medicinal and Pharmaceutical Products & $5.514 * *$ & $-0.35(5.81)^{* *}$ & 1.70 & 0.206 & $(\mathrm{~S})(\mathrm{S})$ & 0.450 & $4.584^{* *}$ & 0.631 \\
\hline 55 Essential Oils & 2.646 & $-0.33(4.02)^{* *}$ & 1.214 & 1.021 & $(\mathrm{~S})(\mathrm{S})$ & 0.437 & 2.267 & $59.726 * *$ \\
\hline 56 Fertilizers & $30.626 * *$ & $-0.83(13.69)^{* *}$ & 2.165 & 1.074 & $(\mathrm{~S})(\mathrm{S})$ & 0.132 & 0.021 & $6.755^{* *}$ \\
\hline 57 Plastics in Primary Form & $6.907 * *$ & $-0.55(6.50)^{* *}$ & 4.05 & 0.198 & $(\mathrm{~S})(\mathrm{S})$ & 0.158 & $6.467 * *$ & 0.541 \\
\hline 58 Plastics in Non-primary Form & $4.118^{* *}$ & $-0.44(5.02)^{* *}$ & 0.321 & 1.510 & $(\mathrm{~S})(\mathrm{S})$ & 0.243 & $5.677 * *$ & $23.106^{* *}$ \\
\hline 59 Chemical Materials & $8.460^{* *}$ & $-0.55(7.20)^{* *}$ & 1.446 & 0.361 & $(\mathrm{~S})(\mathrm{S})$ & 0.449 & 0.602 & $44.155^{* *}$ \\
\hline 61 Leather, Leather MFR & $4.588^{* *}$ & $-0.37(5.30)^{* *}$ & 0.204 & 1.022 & $(\mathrm{~S})(\mathrm{S})$ & 0.327 & 0.791 & $21.677 * *$ \\
\hline 62 Rubber Manufactures & 1.918 & $-0.16(3.43)^{* *}$ & 4.279 & 0.302 & $(\mathrm{~S})(\mathrm{S})$ & 0.677 & 1.347 & $49.202 * *$ \\
\hline 63 Cork and Wood Manufactures & $10.042 * *$ & $-0.53(7.84)^{* *}$ & 1.077 & 1.295 & $(\mathrm{~S})(\mathrm{S})$ & 0.543 & 0.932 & $8.326 * *$ \\
\hline 64 Paper, Paperboard & $9.399 * *$ & $-0.48(7.58)^{* *}$ & 0.486 & 1.021 & (S) (S) & 0.636 & $12.886^{* *}$ & $25.977 * *$ \\
\hline 65 Textile Yarn, Fabrics & 2.077 & $-0.25(3.57)^{* *}$ & 2.094 & 0.896 & (S) (S) & 0.551 & $4.841^{* *}$ & $10.699 * *$ \\
\hline 66 Nonmetallic Mineral & 1.695 & $-0.26(3.22)^{* *}$ & 3.474 & 2.062 & (S) (S) & 0.780 & $7.529 * *$ & $23.549^{* *}$ \\
\hline 67 Iron and Steel & $5.222 * *$ & $-0.37(5.65)^{* *}$ & 2.254 & 1.483 & (S) (S) & 0.388 & $3.688^{* * *}$ & $7.899 * *$ \\
\hline 68 Nonferrous Metals & $4.121 * *$ & $-0.39(5.02)^{* *}$ & 0.150 & 0.075 & (S) (S) & 0.316 & $3.930 * *$ & 0.050 \\
\hline 69 Manufactures of Metals & $7.788 * *$ & $-0.59(6.90)^{* *}$ & 3.244 & 0.513 & (S) (S) & 0.377 & 1.139 & $3.309 *$ \\
\hline 71 Power Generating Machinery & $3.943 * *$ & $-0.27(4.91)^{* *}$ & 3.291 & 1.411 & (S) (S) & 0.698 & 0.425 & $19.444 * *$ \\
\hline 72 Machinery Specialised & 2.176 & $-0.22(3.65)^{* *}$ & 0.248 & 0.200 & (S) (S) & 0.596 & $3.974 * *$ & 1.380 \\
\hline 73 Metalworking Machinery & $4.525 * *$ & $-0.38(5.26)^{* *}$ & 0.451 & 1.192 & $(\mathrm{~S})(\mathrm{S})$ & 0.344 & $12.498 * *$ & $7.327 * *$ \\
\hline 74 General Industrial Machinery & 1.385 & $-0.19(2.91)^{* *}$ & 0.588 & 0.945 & $(\mathrm{~S})(\mathrm{S})$ & 0.472 & $7.822 * *$ & 0.134 \\
\hline 75 Office Machines and ADP Equipment & $3.488^{*}$ & $-0.33(4.62)$ & 2.492 & 2.250 & (S) (S) & 0.608 & 0.037 & $6.218 * *$ \\
\hline 76 Telecommunications Equipment & $5.427 * *$ & $-0.40(5.76)^{*}$ & 0.970 & 0.557 & $(\mathrm{~S})(\mathrm{S})$ & 0.395 & 1.861 & $2.448 * *$ \\
\hline 77 Electrical Machinery, Apparatus \& Appliances & $4.436 * *$ & $-0.40(5.21)^{* *}$ & 2.154 & 1.729 & (S) (S) & 0.741 & $6.553^{* *}$ & $20.278^{* *}$ \\
\hline 78 Motor Vehicles & $3.468 *$ & $-0.38(4.61)^{* *}$ & 1.480 & 0.789 & (S) (S) & 0.365 & 0.054 & 0.833 \\
\hline 79 Transport Equipment & $8.243 * *$ & $-0.59(7.10)^{* *}$ & 0.439 & 1.120 & $(\mathrm{~S})(\mathrm{S})$ & 0.302 & 0.695 & $4.616 * *$ \\
\hline 81 Prefab Buildings; Sanitary, Plumbing, etc. & $36.681^{* *}$ & $-0.86(14.14)^{* *}$ & 0.911 & 1.495 & $(\mathrm{~S})(\mathrm{S})$ & 0.223 & 0.632 & 0.627 \\
\hline 82 Furniture \& Bedding & $4.434 * *$ & $-0.37(5.21)^{* *}$ & 1.492 & 1.732 & (S) (S) & 0.779 & $8.518^{* *}$ & $28.915^{* *}$ \\
\hline 83 Travel Goods, Handbags & $3.133^{*}$ & $-0.35(4.38) * *$ & 1.903 & 0.783 & $(\mathrm{~S})(\mathrm{S})$ & 0.295 & $5.643 * *$ & $9.398 * *$ \\
\hline 84 Articles of Apparel and Clothing & $9.651 * *$ & $-0.38(7.68) * *$ & 0.301 & 1.901 & (S) (S) & 0.924 & 1.732 & $141.40^{* * *}$ \\
\hline 85 Footwear & 1.239 & $-0.05(2.75)^{* *}$ & 0.078 & 2.478 & (S) (S) & 0.869 & 0.246 & $103.13^{* *}$ \\
\hline 87 Professional Scientific Instruments & $9.671^{* *}$ & $-0.58(7.69)$ & 0.352 & 0.309 & (S) $(\mathrm{S})$ & 0.603 & $6.539 * *$ & $16.44 * *$ \\
\hline 88 Photo Appt, Equipment \& Optical Goods & $12.698 * *$ & $-0.55(8.81)^{* *}$ & 0.094 & 0.571 & (S) (S) & 0.751 & 0.713 & $6.721 * *$ \\
\hline
\end{tabular}




\begin{tabular}{|c|c|c|c|c|c|c|c|c|}
\hline 89 Miscellaneous Manufactured Articles & $11.500 * *$ & $-1.15(8.39)^{* *}$ & 0.092 & 0.998 & $(\mathrm{~S})(\mathrm{S})$ & 0.238 & $8.793 * *$ & $2.930 *$ \\
\hline 3 Special Transactions & $43.843 * *$ & $-0.99(16.38)^{* *}$ & 0.726 & 1.661 & $(\mathrm{~S})(\mathrm{S}) 2$ & 0.397 & 0.011 & $59.617 * *$ \\
\hline 95 Coin Including Gold & $35.015^{* *}$ & $-0.94(14.65)^{* *}$ & 0.895 & 0.166 & $(\mathrm{~S})(\mathrm{S})$ & 0.153 & $5.00^{* *}$ & $2.729 *$ \\
\hline 96 Coin (Other Than Gold) & $5.058^{* *}$ & $-0.56(5.61)^{* *}$ & 0.430 & 1.016 & $(\mathrm{~S})(\mathrm{S})$ & 0.346 & 0.181 & 0.092 \\
\hline 97 Gold, Nonmonetary & $9.863 * *$ & $-0.71(7.78)^{* *}$ & 0.982 & 2.229 & (S) (S) & 0.272 & $3.282 *$ & $13.19 * *$ \\
\hline 98 Estimate of Low Valued Import Transactions & $4.190 *$ & $-0.12(5.07)^{* *}$ & 0.297 & 0.609 & $(\mathrm{~S})(\mathrm{S})$ & 0.899 & 0.120 & 0.622 \\
\hline 99 Low Value Shipments & 1.794 & $-0.11(3.31)^{* *}$ & 1.866 & 1.532 & $(\mathrm{~S})(\mathrm{S})$ & 0.797 & 1.255 & $32.16 * *$ \\
\hline
\end{tabular}

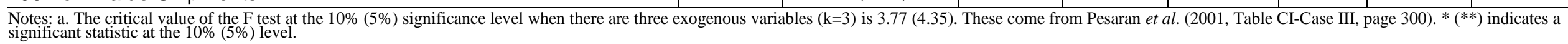

303). Note that these values are for $\mathrm{k} A$.

is the Lagrange Multiplier test of residual serial correlation. It

RESET is Ramsey's test for misspecification. It is distributed as $\chi^{2}$ 


\section{APPENDIX}

\section{Data Definition and Source}

Monthly data over the period January 1996 - April 2018 are used in the empirical analysis. The data come from the following sources:

A. US trade online (https://usatrade.census.gov)

B. International Financial statistics (IFS)

\section{Variables:}

$T B_{i}=$ US trade balance with UK for commodity ' $\mathrm{i}$ ' defined as US imports of commodity ' $\mathrm{i}$ ' from UK divided by US exports of commodity 'i' to UK [Source:A].

$Y_{U K}=\mathrm{UK}$ 's aggregate output as measured by an index of industrial production. [Source:B].

$\mathrm{Y}_{\mathrm{US}}=\mathrm{US}$ aggregate output as measured by an index of industrial production. [Source:B].

$R E X=$ The real bilateral exchange rate of the US dollar against Pounds. It is defined as $R E X=\left(P_{U S}\right.$. $\left.N E X / P_{U K}\right)$ where $N E X$ is the nominal exchange rate defined as number of Pound per USD. Thus, a decline in REX reflects a real depreciation of the USD. Both price levels are measured by CPI. All data come from source B.

\section{Figure 1: Plot of the Real Dollar-Pound Rate}

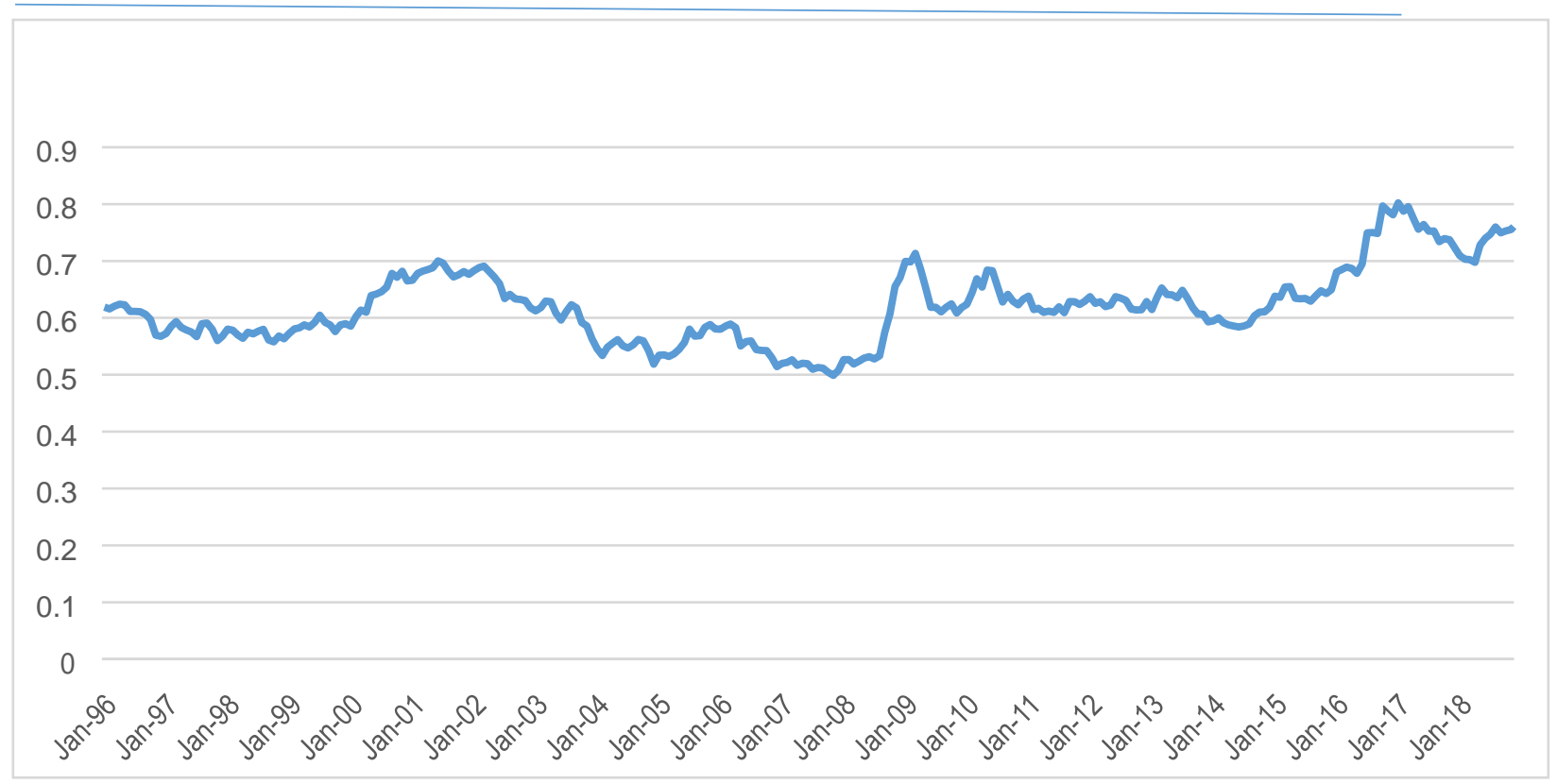

Note: A decline reflects a real depreciation of the dollar. 
It must be noted that following a referendum on June 2016, the UK government formally announced the country's withdrawal from EU. After the announcement, the pound lost its value against major currencies such as the dollar, as seen in Figure 1. However, since the withdrawal has not been settled, the pound has gained back some of the losses. Could our results be affected by this event? Perhaps not since most of the observations in our study period belong to pre-Brexit referendum period. However, we tested our conjecture by including a dummy in the models to account for this event. Our effort was futile in that the dummy was insignificant, as expected. 